\title{
Synthesis, crystal structure, characterizations and magnetic study of a novel two-dimensional Iron fluoride
}

\author{
Sabrine Bouketaya a,b* ${ }^{\text {a }}$, Mouna Smida ${ }^{\text {a }}$, Mohammed S. M. Abdelbaky ${ }^{\text {b }}$, Mohamed Dammak ${ }^{\text {a }}$, Santiago García- \\ Granda $^{\mathrm{b}}$ \\ ${ }^{a}$ Laboratory of Inorganic Chemistry, University of Sfax, B. P. 1171, 3000 Sfax, Tunisia. \\ ${ }^{b}$ Department of Physical and Analytical Chemistry, University of Oviedo-CINN, 33006 Oviedo, Spain.
}

*boukettaya.sabrine@yahoo.fr

\begin{abstract}
A new hybrid compound formulated as $\left[\mathrm{Fe}_{3} \mathrm{~F}_{8}\left(\mathrm{H}_{2} \mathrm{O}\right)_{2}\right]\left(\mathrm{Am}_{2} \mathrm{TAZ}\right)_{2}\left(\mathrm{Am}_{2} \mathrm{TAZ}=3,5\right.$-diamino1,2,4-triazole) was prepared under hydrothermal conditions. The crystal structure was solved by single-crystal X-ray diffraction and the bulk was characterized by thermal analyses (TGMS), vibrational spectroscopy (FTIR, Raman), Ultraviolet-visible spectroscopy (UV-Vis), and scanning electron microscopy (SEM-EDX). It crystallizes in the triclinic system space group $\mathrm{P} \overline{1}$ with unit cell parameters $a=7.100(2) \AA, b=7.658(2) \AA, c=8.321(2) \AA, \alpha=$ $107.330(20)^{\circ}, \beta=111.842(18)^{\circ}, \gamma=93.049(17)^{\circ}, Z=1$ and $V=394.01(17) \AA^{3}$. The studied $\mathrm{X}$-ray crystal structure shows the two oxidation states for iron atoms $\left(\mathrm{Fe}^{2+}, \mathrm{Fe}^{3+}\right)$ and generates a 2D inorganic network, built up of inorganic layers constructed from infinite inorganic chains running along $a$ axis. In fact, these chains are connected via $\left(\mathrm{Fe}^{3+}(3) \mathrm{F}_{6}\right)$ octahedral. OW- $\mathrm{H}^{\cdots}{ }^{\cdots} \mathrm{F}$ and $\mathrm{N}-\mathrm{H}^{\cdots}{ }^{\cdots} \mathrm{F}$ hydrogen bonds, making up the whole 3D network, are strongly linked in the layers. Magnetization measurements were performed, exhibiting the paramagnetic feature of the studied compound above $150 \mathrm{~K}$.
\end{abstract}

Keywords: Fluoride; iron; hydrothermal synthesis; thermal analysis; vibrational spectroscopy; magnetic. 


\section{Introduction}

Extensive research has been focused on the design and the construction of Metal-organic frameworks (MOFs), also known as coordination polymers. They have attracted attention owing to their exceptional structural and chemical diversity in the fields of gas and bioactive molecule storage [1, 2], batteries [3], catalysis [4], luminescence [5] and ion exchange [6]. In fact, the use of porous solids in the health sector is also a very promising application for the vectorization of active drugs in cancer and AIDS fields, in particular [2, 7]. Indeed, Férey and co-workers were the initiator group who attempted to encapsulate and control the release of the active ingredient, Ibuprofen, from porous solids, such as MIL-100 and MIL-101 [8]. The interest for fluorinated hybrid materials is also growing due to the exception of this type to enhance thermal stability, to get low surface tension and to improve physic-chemical performances [9-11].

Hybrid materials can be classified into two distinct classes. These two classes can be distinguished according to the strength of the interactions [12]. In class I hybrids, the organic and inorganic components are associated by weak interactions, such as Van Der Waals, or hydrogen bonds as the case of $\left(\mathrm{H}_{2} \mathrm{dap}\right)_{2}\left[\mathrm{FeF}_{6}\right](\mathrm{F}) \cdot 3 \mathrm{H}_{2} \mathrm{O}$ material [13]. However, in class II hybrids, both parts, organic molecule and inorganic framework, are strongly linked by covalent or ionocovalent bonds like $\mathrm{Fe}_{2} \mathrm{~F}_{5}(\mathrm{taz})$ compound [14]. Each class of hybrid depends not only on the nature of the metallic cations and organic linkers, but also on the reaction conditions such as the solvent, $\mathrm{pH}$, reaction time and the ratio of reactants [15-17].

The most frequently used organic molecules, based on $\mathrm{N}$, contain organic cations, derived from aliphatic $[13,18]$ or cyclic $[19,20]$ amine, are meant to establish covalent or ionocovalent bonds with the metallic cations of 3d-block such as $\mathrm{Fe}, \mathrm{Al}, \mathrm{Zn}, \mathrm{Cu}$. Consequently, numerous fluorinated hybrid materials with designed functionalities and expected properties can be obtained.

Iron fluorides hybrids present the largest variety of inorganic architecture in Class I: isolated polyanions 0D such as $\mathrm{FeF}_{6}[13,21], \mathrm{FeF}_{2}\left(\mathrm{H}_{2} \mathrm{O}\right)_{4}$ [22], $\mathrm{FeF}_{3}\left(\mathrm{H}_{2} \mathrm{O}\right)_{3}$ [23], $\mathrm{FeF}_{5} \mathrm{H}_{2} \mathrm{O}$ [24], and some other compounds contain $\mathrm{Fe}_{2} \mathrm{~F}_{9}$ [25], $\mathrm{Fe}_{2} \mathrm{~F}_{10}$ [26] and $\mathrm{Fe}_{2} \mathrm{~F}_{8}\left(\mathrm{H}_{2} \mathrm{O}\right)_{2}$ [27] dimmers. The infinite chains $1 \mathrm{D}$, exhibiting $\mathrm{FeF}_{6}$ and $\mathrm{Fe}_{2}\left(\mathrm{H}_{2} \mathrm{O}\right)_{2} \mathrm{~F}_{6}$ as octahedral, were reported by Hertweek [28], Frommen [29] and Smida [14], respectively. However, until now, no 2D layers and 3D inorganic network have been evidenced in Class I.

Formally, the literature reports numerous Class II isolated polyhedral (OD) as far as we know $\left[\mathrm{FeF}_{4}(2,2\right.$ '-bpy $\left.)\left(\mathrm{H}_{2} \mathrm{O}\right)_{2}\right]$ [30] and $\mathrm{Fe}_{2} \mathrm{~F}_{5}(2,2 \text { '-bipyridine })_{2} \mathrm{H}_{2} \mathrm{O}$ [31]. On the other hand, 
one hybrid phase with infinite chains (1D) iron fluorides Class II was mentioned by Hongcheng $\mathrm{Lu}$, which is the case of $\mathrm{FeF}_{3}\left(4,4^{\prime}\right.$-bpy) [32]. Few 2D hybrid iron fluorides layers are known and they are obtained with triazole amine and their derivatives such as $\left[\mathrm{Fe}_{3} \mathrm{~F}_{10}\left(\mathrm{H}_{2} \mathrm{amtaz}\right)_{2}\right]$ [33], [( $\left.\left.\mathrm{Fe}_{2} \mathrm{~F}_{5}\left(\mathrm{taz}^{-}\right)_{2}\right) \cdot(\mathrm{Hdma})\right]$ [14] and $\left[\mathrm{Fe}_{2} \mathrm{~F}_{5}\left(\mathrm{H}_{2} \mathrm{O}\right)(\mathrm{Htaz})(\mathrm{taz}) \cdot(\mathrm{Hdma})\right]$ [34]. The most condensed phases, with mixed valence iron cations, are $\mathrm{Fe}_{2} \mathrm{~F}_{5}$ (taz) [14], [Hdma]. $\left(\mathrm{Fe}_{5} \mathrm{~F}_{8}\left(\mathrm{H}_{2} \mathrm{O}\right)_{2}(\text { amtetraz })_{4}\right)$ and $[\mathrm{Hdma}]_{1.5} \cdot\left(\mathrm{Fe}_{5} \mathrm{~F}_{7}\left(\mathrm{H}_{2} \mathrm{O}\right)(\mathrm{HCOO})(\text { amtetraz})_{4}\right)$ [35] with a 3D architecture.

On the basis of the ligand 3,5-diamino-1,2,4-triazole, Abdi and co-workers have synthesized a new iron fluorides hybrid, namely $\left[\mathrm{C}_{2} \mathrm{~N}_{5} \mathrm{H}_{6}\right]_{2} \cdot\left(\mathrm{FeF}_{5}\left(\mathrm{H}_{2} \mathrm{O}\right)\right) \cdot 2 \mathrm{H}_{2} \mathrm{O}$, prepared by solvothermal method during the investigation of $\mathrm{FeF}_{3}$-HFaq-(3,5-diamino-1,2,4-triazole)EtOH system [36]. Due to the presence of both the aromatic linkers and the number of conjugated rings, the ligand 3,5-diamino-1,2,4-triazole, depending on their protonation state, display great coordination diversity.

Furthermore, Lhoste and Cadiau have published new fluorinated hybrid using different metal ions such as $\mathrm{TiF}_{4}$ and $\mathrm{ZnF}_{2}$ with the same ligand 3,5-diamino-1,2,4-triazole, respectively $[19,37]$.

In the scope of this work, and herein, we reported the structure of a new hybrid iron fluorides of class II which was determined by X-Ray diffraction, characterized by thermogravimetric analysis (TG and SDTA), mass spectrometry (m/z 17, m/z 18 and m/z 44), infrared (IR), Raman, UV-Vis diffuse reflectance spectroscopy and its magnetic properties were studied.

\section{Results and Discussion}

\subsection{Crystal structure description}

The detailed information concerning crystallographic data collection and structure refinement are summarized in Table 1. Selected bond distances and angles are shown in Table 2.

The asymmetric unit of the $\left[\mathrm{Fe}_{3} \mathrm{~F}_{8}\left(\mathrm{H}_{2} \mathrm{O}\right)_{2}\right]\left(\mathrm{Am}_{2} \mathrm{TAZ}\right)_{2}$ contains one $\mathrm{Fe}^{2+}$, two $\mathrm{Fe}^{3+}$, four $\mathrm{F}^{-}$ atoms, one coordinated water molecule and one ( $\mathrm{Am}_{2} \mathrm{TAZ}$ ) ligand (Figure S1). The coordination environment of $\mathrm{Fe}^{2+}(1)$ cations contains two fluorine atoms, two coordinated water molecules and two nitrogen atoms; whereas, the $\mathrm{Fe}^{3+}(2)$ cations are bonded to four fluorine atoms and two nitrogen atoms forming $\mathrm{Fe}^{2+}(1) \mathrm{F}_{2} \mathrm{~N}_{2}\left(\mathrm{H}_{2} \mathrm{O}\right)_{2}$ and $\mathrm{Fe}^{3+}(2) \mathrm{F}_{4} \mathrm{~N}_{2}$ octahedral, respectively, with Fe-F distances varying from 1.906(4) $\AA$ to 2.131(4) $\AA$, Fe-OW 
distance equal to 2.089(6) $\AA$ and Fe-N distances varying from 2.097(5) $\AA$ to 2.109(6) $\AA$. Furthermore, the other iron atom $\mathrm{Fe}(3)$ is coordinated by six fluorine atoms forming an $\mathrm{Fe}^{3+}(3) \mathrm{F}_{6}$ octahedron. It displays six $\mathrm{Fe}(3)-\mathrm{F}$ bond length varying between 1.890(4) $\AA$ and 1.957(4) A. These distances are in agreement with the literature [14, 36]. As a result, the compound is a class II hybrid [34] and the oxidation state of each iron atom is confirmed [33]. The main feature of this iron fluoride is the coexistence of two oxidation states for iron atoms $\left(\mathrm{Fe}^{2+}, \mathrm{Fe}^{3+}\right)$ in the unit cell forming a 2D inorganic network.

Each $\mathrm{Fe}^{2+}(1) \mathrm{F}_{2} \mathrm{~N}_{2}\left(\mathrm{H}_{2} \mathrm{O}\right)_{2}$ octahedron is connected with an $\mathrm{Fe}^{3+}(2) \mathrm{F}_{4} \mathrm{~N}_{2}$ octahedron forming dimmers linked by vertex shared at $F(1)$. These dimmers repeated along the [011] direction producing $\left[\mathrm{Fe}_{2} \mathrm{~F}_{5} \mathrm{~N}_{4}\left(\mathrm{H}_{2} \mathrm{O}\right)_{2}\right]_{\infty}$ inorganic-organic hybrid chains. Each chain is, in turn, cross-linked to another octahedron $\mathrm{Fe}^{3+}(3) \mathrm{F}_{6}$ by vertex shared at $\mathrm{F}(2)$ with $\mathrm{Fe}^{3+}(2) \mathrm{F}_{4} \mathrm{~N}_{2}$ exposing a layer developed in the (001) plane (Figure 1). These layers are interconnected via strong $\mathrm{OW}-\mathrm{H}^{\cdots \cdots} \mathrm{F}$ and $\mathrm{N}-\mathrm{H}^{\cdots} \mathrm{F}$ hydrogen bonds. In fact, $\mathrm{OW}{ }^{\cdots \cdots} \mathrm{F}$ and $\mathrm{N}^{\cdots} \mathrm{F}$ corresponded distances vary from $2.65 \AA$ to $3.16 \AA$ (Table S4). Figure 2 clearly elucidates the presence of these hydrogen bonds. This fact accounts for the three-dimensional arrangement of the $\left[\mathrm{Fe}_{3} \mathrm{~F}_{8}\left(\mathrm{H}_{2} \mathrm{O}\right)_{2}\right]\left(\mathrm{Am}_{2} \mathrm{TAZ}\right)_{2}$ structure. Indeed, Figure 3 shows a perspective view of the studied structure.

The same dimensionality for metal-organic network is encountered in $\mathrm{Fe}_{2} \mathrm{~F}_{5}\left(\mathrm{H}_{2} \mathrm{O}\right)(\mathrm{Htaz})(\mathrm{taz})(\mathrm{Hdma})$ compound which crystallizes in the triclinic centrosymmetric space group $P \overline{1}$ [34]. The latter was synthesized in the same conditions as our compound but using (1,2,4-triazole) as organic molecule and DMF as solvent. In the previously mentioned compound, the structure is associated by opposite fluorine corners of $\mathrm{FeF}_{5} \mathrm{~N}$ and $\mathrm{FeF}_{2} \mathrm{~N}_{4}$ octahedral, and/or triazole molecule which generates the 2D material.

\subsection{Thermal behavior}

The thermal analysis (TG, SDTA) of the title compound, in air, was carried out in the temperature range $25-993^{\circ} \mathrm{C}$ and operated at a heating rate of $10^{\circ} \mathrm{C} / \mathrm{min}$ (Figure 4), indicating a total experimental mass loss of $42.4 \%$ (calc $42.28 \%$ ). Figure 4 reveals clearly that no mass variation is detected between 25 and $50^{\circ} \mathrm{C}$ in $\mathrm{TG}$ and no thermal phenomenon is observed in SDTA. Therefore, at room temperature, the material does not exhibit any changes, confirming its stability at room temperature. During the heating process, there are three mass losses at different temperatures. This result was verified by SDTA curves and the mass spectrometric analysis (m/z 17, m/z 18 and m/z 44). 
According to the thermogram shown in Figure 4, this compound reveals three stages. The first and the second steps are continuous with a loss mass of $18.2 \%$ (calc 18.13\%) observed in a temperature range $55-360^{\circ} \mathrm{C}$. This is proved by two endothermic peaks on the SDTA curve at $107^{\circ} \mathrm{C}$ and $275^{\circ} \mathrm{C}$, attributed to the loss of two coordinated water molecules, and $0.65 \mathrm{~mol}$ of the organic molecule $\left(\mathrm{Am}_{2} \mathrm{TAZ}\right.$ ) [30,34]. Above $360^{\circ} \mathrm{C}$, the elimination of $1.35 \mathrm{~mol}$ of $\mathrm{Am}_{2} \mathrm{TAZ}$ and the creation of $\mathrm{FeF}_{3}$ occurred [30]. It corresponds to an experimental mass loss of $24.2 \%$ (calc $24.15 \%$ ). Indeed, this process is represented on the SDTA curve at $375^{\circ} \mathrm{C}$. However, at high temperature, the iron fluoride residues are slightly contaminated by $\mathrm{Fe}_{2} \mathrm{O}_{3}[30]$.

The associated mass spectrometry m/z 17, m/z 18 and m/z 44 curves, observed in Figure 5, are in line with the thermal analysis. We plotted the main volatiles formed during the $\left[\mathrm{Fe}_{3} \mathrm{~F}_{8}\left(\mathrm{H}_{2} \mathrm{O}\right)_{2}\right]\left(\mathrm{Am}_{2} \mathrm{TAZ}\right)_{2}$ decomposition. Accordingly, the curve of the mass spectrometric analysis $\mathrm{m} / \mathrm{z} 17\left(\mathrm{NH}_{3}\right)$ indicated one maxima at $335^{\circ} \mathrm{C}$, thus, proving the decomposition process of the whole organic moiety [34, 38]. Moreover, the curve of the mass spectrometric analysis $\mathrm{m} / \mathrm{z} 18\left(\mathrm{H}_{2} \mathrm{O}\right)$ has two maxima at $283^{\circ} \mathrm{C}$ and $341^{\circ} \mathrm{C}$, respectively. As a result, at this stage, water molecules are disengaged in two steps. In fact, the first peak of $\mathrm{m} / \mathrm{z} 18$ is concurrent with the dehydration of our compound, noting also that the last maxima of $\mathrm{m} / \mathrm{z} 18$ coincides with the only one maxima of $\mathrm{m} / \mathrm{z} 44\left(\mathrm{CO}_{2}\right)$ at the same temperature, $341^{\circ} \mathrm{C}$, attributed to the total decomposition process of ( $\mathrm{Am}_{2} \mathrm{TAZ}$ ). Taking into account that the mass spectrometry is a semi quantitative method, the integration of the second band in the curve of the mass spectrometric analyses $\mathrm{m} / \mathrm{z} 44$ is approximately 0.4 of the integration of the only band in the $\mathrm{m} / \mathrm{z} 17$ curve. This indicates the loss mass of approximately four carbon molecules corresponding to ten nitrogen molecules. This result is confirmed by the chemical formula of our new compound.

In fact, this phenomenon informs that the degradation of the organic molecule is accompanied by the release of carbon dioxide molecules, ammonia molecules and water molecules.

\subsection{Infrared and Raman spectroscopy}

In order to gain more information about the crystal dynamics groups present in the new hybrid $\left[\mathrm{Fe}_{3} \mathrm{~F}_{8}\left(\mathrm{H}_{2} \mathrm{O}\right)_{2}\right]\left(\mathrm{Am}_{2} \mathrm{TAZ}\right)_{2}$ material, spectroscopic studies by Raman diffusion and Infrared were performed.

The infrared and the Raman spectra were analysed, at room temperature, in the frequencies range $4000 \mathrm{~cm}^{-1}$ to $500 \mathrm{~cm}^{-1}$ and $1300 \mathrm{~cm}^{-1}$ to $100 \mathrm{~cm}^{-1}$, respectively, as 
illustrated in Figure 6 and Figure 7. To the best of our knowledge, no Raman spectra at room or variable temperatures have been reported in the literature. The observed bands and their assignments to different modes for $\left[\mathrm{Fe}_{3} \mathrm{~F}_{8}\left(\mathrm{H}_{2} \mathrm{O}\right)_{2}\right]\left(\mathrm{Am}_{2} \mathrm{TAZ}\right)_{2}$ material are given in Table 3 .

In the present investigation, the high frequency, appearing between $3457-3407 \mathrm{~cm}^{-1}$ regions, is probably ascribed to the stretching vibration of coordinated water molecule $v\left(\mathrm{H}_{2} \mathrm{O}\right)$ $[30,31]$; whereas, the asymmetric and symmetric stretching vibrations of amino groups are observed around 3366 and $3344 \mathrm{~cm}^{-1}$ [36,39]. The shoulder peaks at 3227 and $3170 \mathrm{~cm}^{-1}$ and the band appearing at $2384 \mathrm{~cm}^{-1}$ can be attributed to the stretching vibration of the heterocyclic ring of $\mathrm{C}-\mathrm{H}$ bonds [30]. Indeed, the deformations of primary amine are represented on our spectrum in two peaks located around 1660 and $1529 \mathrm{~cm}^{-1}$ [40]. However, in the infrared spectrum, the peak of scissoring vibration $\delta(\mathrm{NH})$ is detected at $1431 \mathrm{~cm}^{-1}$ [36]. In addition to the calculation, these assignments are in agreement with the assignments proposed by George Socrates [41]. Thus, the wave number values of $\mathrm{NH}_{2}$ stretching and scissoring are in accordance with those observed for the hydrated material iron fluorides established by Insaf Abdi [36]. Moreover, the strong peak at $1636 \mathrm{~cm}^{-1}$ in infrared spectrum can be related to the stretching vibration of $(\mathrm{C}=\mathrm{N})$ of the cyclic amine [42].

In addition, in a frequency region of $1324-1126 \mathrm{~cm}^{-1}$ of infrared spectrum and around 1261 and $1220 \mathrm{~cm}^{-1}$ of the Raman spectrum for compounds with (Am $2 \mathrm{TAZ}$ ) molecules, we may except the stretching vibration of $(\mathrm{C}-\mathrm{N})$ of the heterocyclic ring [40].

In the Raman spectrum, the broad band detected in the range 1139 to $1051 \mathrm{~cm}^{-1}$ can be attributed to the rocking vibration of $\mathrm{NH}_{2}$. However, in the same range of infrared spectrum, the strong peak, observed at $1045 \mathrm{~cm}^{-1}$, corresponds to the stretching vibration of $v(\mathrm{~N}-\mathrm{N})$ [36]. This is also in accordance with the compound which has already been studied in the literature, such as $\left[\mathrm{C}_{2} \mathrm{~N}_{5} \mathrm{H}_{6}\right]_{2} \cdot\left(\mathrm{FeF}_{5}\left(\mathrm{H}_{2} \mathrm{O}\right)\right) \cdot 2 \mathrm{H}_{2} \mathrm{O}[36]$.

The wagging vibrations $\omega\left(\mathrm{NH}_{2}\right)$ appears not only around 832 and $757 \mathrm{~cm}^{-1}$ in the IR spectrum, but also around 910 and $659 \mathrm{~cm}^{-1}$ in the Raman spectrum [39, 40].

The band observed, ranging from 692 to $602 \mathrm{~cm}^{-1}$, in the infrared spectrum, can be associated with the deformation in the plane of $\delta\left(\mathrm{C}-\mathrm{NH}_{2}\right)$. On the other hand, this mode is represented by the peak at $390 \mathrm{~cm}^{-1}$ in the Raman spectrum [40]. According to the reviewer James Kincaid, the strong band, detected at 590 and $531 \mathrm{~cm}^{-1}$ can be ascribed to the presence of the stretching vibration of the inorganic group $v\left(\mathrm{FeF}_{6}\right)$ [43]. Eventually, the stretching vibration of the metal ligand group $v\left(\mathrm{FeF}_{2} \mathrm{~N}_{2} \mathrm{O}_{2}\right)$ and $v\left(\mathrm{FeF}_{4} \mathrm{~N}_{2}\right)$ are related to these two strong peaks detected at 279 and $217 \mathrm{~cm}^{-1}$ [44,45]. Accordingly, the vibrational frequencies of the fundamental modes of the new compound $\left[\mathrm{Fe}_{3} \mathrm{~F}_{8}\left(\mathrm{H}_{2} \mathrm{O}\right)_{2}\right]\left(\mathrm{Am}_{2} \mathrm{TAZ}\right)_{2}$ were specifically 
assigned by studying the IR and Raman spectra and confirmed by the presence of coordinating 3,5-diamino-1,2,4-triazole organic molecule. Moreover, the spectroscopic characterization proves the class II of this new material.

A future study by Raman, at different temperatures, will be realized to confirm the thermal phenomenon of our compound.

\subsection{Optical study}

Figure 8 displays the UV-Vis diffuse-reflectance spectrum of $\left[\mathrm{Fe}_{3} \mathrm{~F}_{8}\left(\mathrm{H}_{2} \mathrm{O}\right)_{2}\right]\left(\mathrm{Am}_{2} \mathrm{TAZ}\right)_{2}$ after the application of the Kubelka-Munk transformation. The energy gap value of this compound was measured, being about $3.44 \mathrm{ev}$ on the corresponding $\lambda_{\mathrm{abs}}(360.4 \mathrm{~nm})$. However, this new iron fluoride material presents a stronger optical absorption in the ultraviolet (UV) region $(\lambda<400 \mathrm{~nm})$ and a good transparency in the visible range. A similar observed curve, shown for $\mathrm{Fe}_{2} \mathrm{~F}_{5}\left(\mathrm{H}_{2} \mathrm{O}\right)(\mathrm{Htaz})(\mathrm{taz})(\mathrm{Hdma})$ compound [34], reports an energy gap value about $3.47 \mathrm{ev}$. This latter, in particular, is obtained by $\mathrm{FeF}_{2} / \mathrm{FeF}_{3^{-}}$1, 2, 4-triazol- $\mathrm{HF}$ (hydrofluoric acid solution) system and dimethylformamide (DMF) as solvent, and it describes the same dimensionality 2D and the presence of two oxidation state of iron, as compared with our new compound. These optical gap values of these iron fluorides belong to the similar area of oxyfluorotitanate [37].

Therefore, an optical study of our new material $\left[\mathrm{Fe}_{3} \mathrm{~F}_{8}\left(\mathrm{H}_{2} \mathrm{O}\right)_{2}\right]\left(\mathrm{Am}_{2} \mathrm{TAZ}\right)_{2}$ displayed a high absorption in the Ultraviolet and a good transparency in the Visible range with a gap value, included in the zone of complexes, that contains a metal cation bound by ligands of an organic molecule such as $\mathrm{Fe}-\mathrm{N}$.

\subsection{Magnetization measurements}

Figure 9 exhibits the evolution of the inverse molar susceptibility $\left(\chi_{m}{ }^{-1}\right)$ and the specific magnetization $(\sigma)$ measured under an applied magnetic field of $10 \mathrm{kOe}$ for $\left[\mathrm{Fe}_{3} \mathrm{~F}_{8}\left(\mathrm{H}_{2} \mathrm{O}\right)_{2}\right]\left(\mathrm{Am}_{2} \mathrm{TAZ}\right)_{2}$ over the whole temperature range 100-400 $\mathrm{K}$. The magnetic susceptibility of the studied compound is characterized by exhibiting a paramagnetic behaviour above $150 \mathrm{~K}$. It is in good agreement with the magnetic data, since it follows a Curie-Weiss law with paramagnetic effective moments. Furthermore, magnetization curves $\mathrm{M}(\mathrm{H})$, during a close loop with maximum applied field of $20 \mathrm{kOe}$ at room temperature, is represented in Figure 10. The general shape of the curve is a linear increase, and it obeys the Brillouin function [46]. Moreover, the curve does not display any irreversibility consistency with a paramagnetic behavior [47]. Table 4 reveals the magnetic magnitudes obtained in this 
compound. Actually, the value of the experimental paramagnetic effective moment $6.90 \mu_{B}$ is quite close to that expected theoretically $6.92 \mu_{B}$ for iron ion (terms): $\mathrm{Fe}^{3+}\left({ }^{6} \mathrm{~S}_{5 / 2}\right)$ and $\mathrm{Fe}^{2+}$ $\left({ }^{5} \mathrm{D}_{4}\right)$.

A recent example shows the same paramagnetic response, which is the case of the mixed monohydrate iron fluorides, $\mathrm{Fe}_{2} \mathrm{~F}_{5}(2,2 \text { '-bipyridine })_{2} \mathrm{H}_{2} \mathrm{O}$ [31]. The fitted parameters for the Curie-Weiss laws indicate both complex ionic states for the iron atoms.

Therefore, the magnetic characterization for this new compound $\left[\mathrm{Fe}_{3} \mathrm{~F}_{8}\left(\mathrm{H}_{2} \mathrm{O}\right)_{2}\right]\left(\mathrm{Am}_{2} \mathrm{TAZ}\right)_{2}$, follows Curie-Weiss law and reveals a paramagnetic behaviour above $150 \mathrm{~K}$. To provide our interpretation, we can perform several $\mathrm{M}(\mathrm{H})$ curves at temperatures below $150 \mathrm{~K}$ and applied magnetic fields, to settle down the magnetic nature of this studied material. Similarly, Mossbauer studies, eventually in the presence of a magnetic field, could prove very helpful in order to determine the magnetization at various iron sites.

\section{Materials and methods}

\subsection{Synthesis of $\left[\mathrm{Fe}_{3} \mathrm{~F}_{8}\left(\mathrm{H}_{2} \mathrm{O}\right)_{2}\right]\left(\mathrm{Am}_{2} \mathrm{TAZ}\right)_{2}$}

The reaction mixture for the synthesis of new class II hybrid fluorinated is formed by two metal cations in fluorinated forms $\mathrm{FeF}_{2}$ and $\mathrm{FeF}_{3}$, an aqueous solution of hydrofluoric acid $4 \%$ (prepared from $40 \% \mathrm{HF}$, Riede-deHaen), a solvent such as ethanol, which is polar and protic, and with a cyclic organic molecule (3,5-diamino-1,2,4-triazole). The solvent volume was fixed to $10 \mathrm{~mL}$ with a constant concentration $\left[\mathrm{Fe}^{\mathrm{II}}\right]+\left[\mathrm{Fe}^{\mathrm{III}}\right]=0.15 \mathrm{~mol} \cdot \mathrm{L}^{-1}$ and an equimolar ratio $\mathrm{n}\left(\mathrm{Fe}^{\mathrm{II}}\right) / \mathrm{n}\left(\mathrm{Fe}^{\mathrm{III}}\right)=1$. Indeed, $\left[\mathrm{Fe}_{3} \mathrm{~F}_{8}\left(\mathrm{H}_{2} \mathrm{O}\right)_{2}\right]\left(\mathrm{Am}_{2} \mathrm{TAZ}\right)_{2}$ is obtained from a mixture of $85 \mathrm{mg}$ of $\mathrm{FeF}_{3}(0.75 \mathrm{mmol}), 70 \mathrm{mg}$ of $\mathrm{FeF}_{2}(0.75 \mathrm{mmol}), 2.52 \mathrm{~mL}$ of $\mathrm{HF} 2.3 \mathrm{M}$ (5.8 mmol) and $57 \mathrm{mg}\left(\mathrm{Am}_{2} \mathrm{TAZ}\right)(0.57 \mathrm{mmol})$.

The starting materials were placed in a reactor when filling $50 \%$ of the autoclave. After manipulation, the solid product is washed with the solvent used, then air dried at room temperature. As a result, a new mixed hybrid fluoride was obtained. Therefore, the exploration of this system $\mathrm{FeF}_{2} / \mathrm{FeF}_{3}-\mathrm{HF}-\left(\mathrm{Am}_{2} \mathrm{TAZ}\right)-\mathrm{EtOH}$, led by hydrothermal synthesis at $120^{\circ} \mathrm{C}$ for 72 hours, yielded to the elaboration of a new phase of formula $\left[\mathrm{Fe}_{3} \mathrm{~F}_{8}\left(\mathrm{H}_{2} \mathrm{O}\right)_{2}\right]\left(\mathrm{Am}_{2} \mathrm{TAZ}\right)_{2}$ colorless with prismatic shape.

\subsection{Crystal structure determination}

The single crystal was selected by using a polarizing microscope. X-Ray crystal data were collected at room temperature, on an Agilent Gemini CCD diffractometer using $\mathrm{CuK} \alpha$ 
radiation. The structure was determined by direct methods, using SHELXS-86 [48], that give positions of most atoms (iron, nitrogen, fluorine atoms), extended by successive difference Fourier maps, and refined by full-matrix least square on all $\mathrm{F}^{2}$ data using SHELXL-97 [49]. All non-H atoms were anisotropically refined. All $\mathrm{H}$ atoms were either geometrically placed riding on their parent atoms or located from the difference Fourier map, with isotropic displacement parameters set to 1.2 times the Ueq of the atoms to which they are attached. These programs were included in WINGX package [50]. The projections of this structure were performed with the DIAMOND program [51].

The powder X-ray diffraction (PXRD) was recorded on a Siemens D5000 powder diffractometer, using $\mathrm{Cu} \mathrm{K}$ a radiation (1.542 $\AA$ ) with a $2 \theta$ range of $10-40^{\circ}$. The simulation of the PXRD spectra was carried out by the single-crystal data and Oscail (4.6.1) program (Figure S2).

\subsection{Morphological characterization}

SEM micrographs and X-ray microanalysis (SEM/EDX) were recorded using a JEOL6610LV scanning electron microscope, operating at $30 \mathrm{kV}$, coupled with an Oxford X-Max microanalysis system (EDX). Scanning electronic microscopy exhibited the morphology of $\left[\mathrm{Fe}_{3} \mathrm{~F}_{8}\left(\mathrm{H}_{2} \mathrm{O}\right)_{2}\right]\left(\mathrm{Am}_{2} \mathrm{TAZ}\right)_{2}$ and confirmed that all non-hydrogen atoms are present: Fe, F, O, N and C (Figure S3, Figure S4).

\subsection{Thermal characterization}

A Mettler Toledo TGA/SDTA851ELF was used for the thermal analyses in oxygen dynamic atmosphere $(50 \mathrm{~mL} / \mathrm{min})$ at a heating rate of $10^{\circ} \mathrm{C} / \mathrm{min}$. The sample mass used in TG and SDTA measurements was $12.444 \mathrm{mg}$. In parallel with TG tests, a Pfeiffer Vaccum ThermoStarTM GSD301T mass spectrometer was employed to determine the evacuated vapours. The masses $17\left(\mathrm{NH}_{3}\right), 18\left(\mathrm{H}_{2} \mathrm{O}\right)$ and $44\left(\mathrm{CO}_{2}\right)$ were tested by using a detector C-SEM, operating at $1200 \mathrm{~V}$, with a constant time of $1 \mathrm{~s}$.

\subsection{Infrared and Raman spectra}

Infrared absorption spectra of suspension of crystalline in $\mathrm{KBr}$ were recorded on a JascoFT-IR-420 spectrophotometer in the $4000-400 \mathrm{~cm}^{-1}$ frequency range. Raman spectrum was measured with a LABHARAM HR 800 triple monochromatic in the $1500-100 \mathrm{~cm}^{-1}$ region. The powder sample was mounted on a quartz support to minimize the background. 


\subsection{UV-vis study}

The UV-Vis spectral analysis was carried out between 200 and $800 \mathrm{~nm}$ using UV-Vis absorption spectrophotometer (T90+UV/Visible). The UV-Vis diffuse-reflectance spectrum was measured at a room temperature between $6.2-1.55 \mathrm{eV}$ using OLIS 14-VIS-NIR spectroscopy operating system. The reflectivity spectra were transformed to absorption $(\alpha / S)$ spectra by the Kubelka-Munk function: $F(R)=\alpha / S=(1-R)^{2} / 2 R$, where $R$ is the reflectivity at a given wavelength, $\alpha$ is the absorption coefficient, and $\mathrm{S}$ is the scattering coefficient $[52,53]$. The optical gap value was determined from the intersection of the wavelength axis and the extrapolated line of the linear portion at the absorption threshold.

\subsection{Magnetic study}

Magnetic properties of iron fluoride were examined by vibrating sample magnetometer (VSM) on an EV9 instrument. $\mathrm{M}(\mathrm{H})$ curves at room temperature and magnetization, temperature dependence, $\mathrm{M}(\mathrm{T})$ curves, under applied magnetic field of $10 \mathrm{kOe}(\approx 796 \mathrm{kA} / \mathrm{m})$ were carried out in order to study the behavior of molar susceptibility of our compound.

\section{Conclusion}

To sum up, $\left[\mathrm{Fe}_{3} \mathrm{~F}_{8}\left(\mathrm{H}_{2} \mathrm{O}\right)_{2}\right]\left(\mathrm{Am}_{2} \mathrm{TAZ}\right)_{2}$ is a new hybrid material based on $\mathrm{Fe}(\mathrm{III})$ and $\mathrm{Fe}(\mathrm{II})$ fluorinated entities and $\left(\mathrm{Am}_{2} \mathrm{TAZ}\right)$ cations as organic counterparts. This iron fluoride was synthesized using sub-critical hydrothermal method in ethanol as solvent. The crystal structure, determined by X-ray diffraction, can be described as layers built up from $\left(\mathrm{Fe}_{2} \mathrm{~F}_{5} \mathrm{~N}_{4}\left(\mathrm{H}_{2} \mathrm{O}\right)_{2}\right) \infty$ chains, $\mathrm{FeF}_{6}$ octahedral and neutral organic molecules $\left(\mathrm{Am}_{2} \mathrm{TAZ}\right)$. These layers are interconnected via strong hydrogen bond, forming the whole structure of the novel iron fluoride $\left[\mathrm{Fe}_{3} \mathrm{~F}_{8}\left(\mathrm{H}_{2} \mathrm{O}\right)_{2}\right]\left(\mathrm{Am}_{2} \mathrm{TAZ}\right)_{2}$.

This structure determined by the notation of Cheetham et al [54] shows 2-D dimensionality with respect to both organic molecules connecting metal centres $\left(\mathrm{O}^{\mathrm{n}}\right)$ and extended inorganic connectivity $\left(\mathrm{I}^{\mathrm{n}}\right)$. Therefore, the notation of Cheetham is $\mathrm{I}^{0} \mathrm{O}^{2}(\mathrm{I}=$ inorganic and $\mathrm{O}=$ organic), taking into account that the sum of the exponents yields the overall dimensionality of the structure.

The results of thermal analysis suggest that the decomposition occurred at three steps, in a temperature range of $25-993^{\circ} \mathrm{C}$. IR and Raman spectroscopic studies confirm the presence of coordinating $\left(\mathrm{Am}_{2} \mathrm{TAZ}\right)$ organic molecules. Magnetization measurements indicate that $\left[\mathrm{Fe}_{3} \mathrm{~F}_{8}\left(\mathrm{H}_{2} \mathrm{O}\right)_{2}\right]\left(\mathrm{Am}_{2} \mathrm{TAZ}\right)_{2}$ is paramagnetic above $150 \mathrm{~K}$. 
Supplementary materials: Table S1: Table of abbreviations; Table S2: Fractional atomic coordinates and isotropic or equivalent isotropic displacement parameters (Å2); Table S3: Factors of anisotropic thermal agitation of $\left[\mathrm{Fe}_{3} \mathrm{~F}_{8}\left(\mathrm{H}_{2} \mathrm{O}\right)_{2}\right]\left(\mathrm{Am}_{2} \mathrm{TAZ}\right)_{2}$ crystal; Table S4: Hydrogen-bond geometry in $\left[\mathrm{Fe}_{3} \mathrm{~F}_{8}\left(\mathrm{H}_{2} \mathrm{O}\right)_{2}\right]\left(\mathrm{Am}_{2} \mathrm{TAZ}\right)_{2}\left(\AA{ }^{\circ}{ }^{\circ}\right)$; Figure S1: Perspective view of the asymmetric unit of $\left[\mathrm{Fe}_{3} \mathrm{~F}_{8}\left(\mathrm{H}_{2} \mathrm{O}\right)_{2}\right]\left(\mathrm{Am}_{2} \mathrm{TAZ}\right)_{2}$; Figure $\mathrm{S} 2$ : Powder XRD pattern of $\left[\mathrm{Fe}_{3} \mathrm{~F}_{8}\left(\mathrm{H}_{2} \mathrm{O}\right)_{2}\right]\left(\mathrm{Am}_{2} \mathrm{TAZ}\right)_{2}$, compared with the calculated; Figure S3: SEM image of $\left[\mathrm{Fe}_{3} \mathrm{~F}_{8}\left(\mathrm{H}_{2} \mathrm{O}\right)_{2}\right]\left(\mathrm{Am}_{2} \mathrm{TAZ}\right)_{2} ;$ Figure $\mathrm{S} 4$ : SEM image and EDX spectra of $\left[\mathrm{Fe}_{3} \mathrm{~F}_{8}\left(\mathrm{H}_{2} \mathrm{O}\right)_{2}\right]\left(\mathrm{Am}_{2} \mathrm{TAZ}\right)_{2}$.

Supporting Information: Crystallographic data for the structural analyses were deposited with the Cambridge Crystallographic Data Center 1473715 for the complex.

Acknowledgments: We acknowledge financial support from the Ministry of Higher Education and Scientific Research of Tunisia and Spanish Ministerio de Economía y Competitividad (MAT2016-78155-C2-1-R and FPI grant BES-2011-046948 to MSM.A.). All the authors would like to express their gratitude to Dr. David Martinez Blanco, for his help in the vibrating sample magnetometer on an EV9 instrument, to Pr. Hamadi Khemakhem, for his help in the spectroscopic Raman measurements, and to Mr. Wassim Hariz, for language proofreading and polishing services.

\section{References}

[1] D.J. Collins, H.-C. Zhou, Hydrogen storage in metal-organic frameworks, J. Mater. Chem. 17 (2007) 3154-3160. doi:10.1039/B702858J.

[2] P. Horcajada, T. Chalati, C. Serre, B. Gillet, C. Sebrie, T. Baati, J.F. Eubank, D. Heurtaux, P. Clayette, C. Kreuz, J.-S. Chang, Y.K. Hwang, V. Marsaud, P.-N. Bories, L. Cynober, S. Gil, G. Férey, P. Couvreur, R. Gref, Porous metal-organic-framework nanoscale carriers as a potential platform for drug delivery and imaging, Nat. Mater. 9 (2010) 172-178. doi:10.1038/nmat2608.

[3] G. Férey, F. Millange, M. Morcrette, C. Serre, M.-L. Doublet, J.-M. Grenèche, J.-M. Tarascon, Mixed-valence li/fe-based metal-organic frameworks with both reversible redox and sorption properties, Angew. Chem. Int. Ed Engl. 46 (2007) 3259-3263. doi:10.1002/anie.200605163.

[4] F. Gándara, B. Gomez-Lor, E. Gutiérrez-Puebla, M. Iglesias, M.A. Monge, D.M. Proserpio, N. Snejko, An Indium Layered MOF as Recyclable Lewis Acid Catalyst, Chem. Mater. 20 (2008) 72-76. doi:10.1021/cm071079a.

[5] J.-P. Zhang, Y.-Y. Lin, X.-C. Huang, X.-M. Chen, Copper(I) 1,2,4-triazolates and related complexes: studies of the solvothermal ligand reactions, network topologies, and photoluminescence properties, J. Am. Chem. Soc. 127 (2005) 5495-5506. doi:10.1021/ja042222t.

[6] S.R. Halper, L. Do, J.R. Stork, S.M. Cohen, Topological Control in Heterometallic Metal-Organic Frameworks by Anion Templating and Metalloligand Design, J. Am. Chem. Soc. 128 (2006) 15255-15268. doi:10.1021/ja0645483. 
[7] P. Horcajada, R. Gref, T. Baati, P.K. Allan, G. Maurin, P. Couvreur, G. Férey, R.E. Morris, C. Serre, Metal-organic frameworks in biomedicine, Chem. Rev. 112 (2012) 1232-1268. doi:10.1021/cr200256v.

[8] P. Horcajada, C. Serre, M. Vallet-Regí, M. Sebban, F. Taulelle, G. Férey, Metal-organic frameworks as efficient materials for drug delivery, Angew. Chem. 118 (2006) 6120-6124.

[9] C. Yang, X. Wang, M.A. Omary, Fluorous Metal-Organic Frameworks for High-Density Gas Adsorption, J. Am. Chem. Soc. 129 (2007) 15454-15455. doi:10.1021/ja0775265.

[10] P. Pachfule, Y. Chen, S.C. Sahoo, J. Jiang, R. Banerjee, Structural isomerism and effect of fluorination on gas adsorption in copper-tetrazolate based metal organic frameworks, Chem. Mater. 23 (2011) 2908-2916.

[11] C. Serre, Superhydrophobicity in Highly Fluorinated Porous Metal-Organic Frameworks, Angew. Chem. Int. Ed. 51 (2012) 6048-6050. doi:10.1002/anie.201201440.

[12] C. Sanchez, F. Ribot, Design of hybrid organic-inorganic materials synthesized via sol-gel chemistry, New J. Chem. 18 (1994) 1007-1047.

[13] A. Zouaghi, A. BenAli, V. Maisonneuve, M. Leblanc, Bis(propane-1,3-diaminium) hexa-fluoridoferrate(III) fluoride trihydrate, Acta Crystallogr. Sect. E Struct. Rep. Online. 66 (2010) m702-m703. doi:10.1107/S1600536810018039.

[14] M. Smida, J. Lhoste, V. Pimenta, A. Hémon-Ribaud, L. Jouffret, M. Leblanc, M. Dammak, J.-M. Grenèche, V. Maisonneuve, New series of hybrid fluoroferrates synthesized with triazoles: various dimensionalities and Mössbauer studies, Dalton Trans. 42 (2013) 15748-15755. doi:10.1039/C3DT51812D.

[15] C. Sanchez, B. Julián, P. Belleville, M. Popall, Applications of hybrid organic-inorganic nanocomposites, J. Mater. Chem. 15 (2005) 3559-3592. doi:10.1039/B509097K.

[16] Z. Su, J. Fan, T. Okamura, W.-Y. Sun, N. Ueyama, Ligand-Directed and pH-Controlled Assembly of Chiral 3d-3d Heterometallic Metal-Organic Frameworks, Cryst. Growth Des. 10 (2010) 3515-3521. doi:10.1021/cg100418a.

[17] J.-Q. Liu, Y.-Y. Wang, Y.-N. Zhang, P. Liu, Q.-Z. Shi, S.R. Batten, Topological Diversification in Metal-Organic Frameworks: Secondary Ligand and Metal Effects, Eur. J. Inorg. Chem. 2009 (2009) 147-154. doi:10.1002/ejic.200800898.

[18] M.A. Saada, V. Maisonneuve, J. Marrot, N. Mercier, M. Leblanc, A. Hémon-Ribaud, [H3tren]3+ and [H4tren]4+ fluoride zirconates or tantalates, J. Fluor. Chem. 132 (2011) 732-739. doi:10.1016/j.jfluchem.2011.05.007.

[19] A. Cadiau, C. Martineau, F. Taulelle, K. Adil, Investigation of the composition space diagram of the $\mathrm{ZnF} 2-3,5$-diamino-1,2,4-triazole-HF-H2O chemical system and structural characterization of a new fluorinated guanazolate MOF [Zn3F2].(Am2TAZ)4, J. Fluor. Chem. 150 (2013) 104108. doi:10.1016/j.jfluchem.2013.02.016.

[20] N. Klein, H.C. Hoffmann, A. Cadiau, J. Getzschmann, M.R. Lohe, S. Paasch, T. Heydenreich, K. Adil, I. Senkovska, E. Brunner, S. Kaskel, Structural flexibility and intrinsic dynamics in the $\mathrm{M} 2$ (2,6-ndc)2(dabco) $(\mathrm{M}=\mathrm{Ni}, \mathrm{Cu}, \mathrm{Co}, \mathrm{Zn})$ metal-organic frameworks, J. Mater. Chem. 22 (2012) 10303-10312. doi:10.1039/C2JM15601F.

[21] K. Adil, A. Ben Ali, M. Leblanc, V. Maisonneuve, On isoelectronic fluorides $[\mathrm{H} 3$ tren $] \cdot(\mathrm{AlF} 6) \cdot \mathrm{H} 2 \mathrm{O}, \quad[\mathrm{H} 3 \mathrm{tren}] \cdot(\mathrm{AlF} 6) \cdot \mathrm{HF}, \quad[\mathrm{H} 4 \mathrm{tren}] \cdot(\mathrm{AlF} 6) \cdot(\mathrm{F})$ and the iron analogue

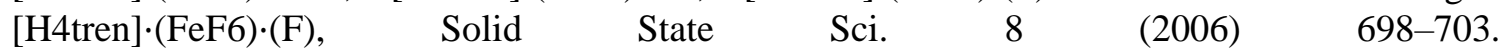
doi:10.1016/j.solidstatesciences.2006.02.035.

[22] A.B. Ali, J.-M. Grenèche, M. Leblanc, V. Maisonneuve, [H3tren]3+ templated iron fluorides; synthesis, crystal structures and Mössbauer studies, Solid State Sci. 11 (2009) 1631-1638. doi:10.1016/j.solidstatesciences.2009.06.003.

[23] K. Adil, M.A. Saada, A.B. Ali, M. Body, M.T. Dang, A. Hémon-Ribaud, M. Leblanc, V. Maisonneuve, Hydrogen bonded $\mathrm{H} 3 \mathrm{O}+, \mathrm{H} 2 \mathrm{O}, \mathrm{HF}, \mathrm{F}-$ in fluoride metalates ( $\mathrm{Al}, \mathrm{Cr}, \mathrm{Fe}, \mathrm{Zr}, \mathrm{Ta}$ ) templated with tren (tris-(2-aminoethyl)amine), J. Fluor. Chem. 128 (2007) 404-412. doi:10.1016/j.jfluchem.2006.10.015.

[24] S.T. Malinovskii, E.B. Coropceanu, P.N. Bourosh, A.P. Rija, O.A. Bologa, M. Gdaniec, I.N. Bulhac, Synthesis and structure of cobalt(III) dimethylglyoximate with $[\mathrm{FeF} 5(\mathrm{H} 2 \mathrm{O})] 2-$ anion, Russ. J. Coord. Chem. 34 (2008) 422-426. doi:10.1134/S1070328408060055. 
[25] L. Kiriazis, R. Mattes, Ein- und zweikernige Fluorokomplexe des Titan(III), Chrom(III) und Eisen(III) Darstellung und Struktur von (NMe4)(Ti(H2O)4F2)TiF6 · H2O, (NMe4)3Cr2F9 und (NMe4)3Fe2F9, Z. Für Anorg. Allg. Chem. 593 (1991) 90-98. doi:10.1002/zaac.19915930109.

[26] G. Darmograi, L. Jouffret, A. Hémon-Ribaud, M. Leblanc, G. Dujardin, V. Maisonneuve, J. Lhoste, Fluoroferrates with (dabcoH2)2+ or (dabcoH)+ Cations, Z. Für Anorg. Allg. Chem. 640 (2014) 1385-1391. doi:10.1002/zaac.201300656.

[27] U. Bentrup, Massa,W, Naturforsch,Z, Die Kristallstruktur von [(CH3)4]FeF4.H2O mit einem di(l-fluoro)-ver bruck ten [Fe2F8(H2O)2]2-anion. Z. Naturforsch. B:, Chem Sci. (1991) 395399.

[28] E. Herdtweck, J. Graulich, D. Babel, The chain structures of the ternary iron(III) fluorides Rb2FeF5 and (CH3NH3)2FeF5. Z. Naturforsch. B., Chem Sci. (1990) 161-169.

[29] C. Frommen, L. Schroder, W. Massa, J. Pebler, U. Bentrup, Magnetic studies on the 1-D antiferromagnetic chains of en H2Mn(Fe)F5. Z. Naturforsch. B., Chem Sci. (1995) 1627-1637.

[30] M. Smida, H. Litaiem, M. Dammak, S. Garcia-Granda, Structure, thermal behavior and characterization of a new hybrid iron fluoride FeF4(2,2'-bipyridine)(H2O)2, Chem. Res. Chin. Univ. 31 (2015) 16-20. doi:10.1007/s40242-015-4171-x.

[31] M. Smida, M. Dammak, S. Garcia-Granda, A new hybrid iron fluoride bipyridine with mixed valence: Fe2F5(2,2'-bipyridine)2H2O, IJC- Vol55A07 July $2016 . \quad$ (2016). http://nopr.niscair.res.in/handle/123456789/35069 (accessed August 27, 2016).

[32] H. Lu, T. Yamamoto, W. Yoshimune, N. Hayashi, Y. Kobayashi, Y. Ajiro, H. Kageyama, A Nearly Ideal One-Dimensional $S=5 / 2$ Antiferromagnet FeF3(4,4'-bpy) (4,4'-bpy $=4,4$ 'bipyridyl) with Strong Intrachain Interactions, J. Am. Chem. Soc. 137 (2015) 9804-9807. doi:10.1021/jacs.5b06120.

[33] I. Abdi, J. Lhoste, M. Leblanc, V. Maisonneuve, J.-M. Grenèche, G. Viau, A. Ben Ali, [H2amtaz]+ iron fluorides: Synthesis, crystal structures, magnetic and Mössbauer studies, J. Fluor. Chem. 173 (2015) 23-28. doi:10.1016/j.jfluchem.2015.01.017.

[34] M. Smida, J. Lhôste, M. Dammak, S. Garcia-Granda, Hydrothermal synthesis, thermal decomposition and optical properties of $\mathrm{Fe} 2 \mathrm{~F} 5(\mathrm{H} 2 \mathrm{O})(\mathrm{Htaz})(\mathrm{taz})(\mathrm{Hdma})$, Arab. J. Chem. (n.d.). doi:10.1016/j.arabjc.2015.04.023.

[35] V. Pimenta, Q.H.H. Le, L. Clark, J. Lhoste, A. Hémon-Ribaud, M. Leblanc, J.-M. Grenèche, G. Dujardin, P. Lightfoot, V. Maisonneuve, New iron tetrazolate frameworks: synthesis, temperature effect, thermal behaviour, Mössbauer and magnetic studies, Dalton Trans. Camb. Engl. 2003. 44 (2015) 7951-7959. doi:10.1039/c5dt00281h.

[36] I. Abdi, F. Alzahrany, J. Lhoste, J.-M. Greneche, A.B. Ali, Synthesis, crystal structure and Mössbauer study of new iron fluoride [C2N5H6]2•(FeF5(H2O)•2H2O, J. Adv. Chem. 10 (2014) 2617-2624.

[37] J. Lhoste, C. Galven, M. Leblanc, V. Maisonneuve, X. Rocquefelte, S. Jobic, M. Bujoli-Doeuff, Crystal structure and optical properties of new 0D-hybrid hydroxyfluorotitanates, Solid State Sci. 24 (2013) 101-106. doi:10.1016/j.solidstatesciences.2013.07.014.

[38] A. Cadiau, A.L. Bail, A. Hémon-Ribaud, M. Leblanc, M. Body, F. Fayon, E. Durand, J.-C. Boulou, V. Maisonneuve, Evolution of Guanazolium Fluoroaluminates within the CompositionSpace Diagram and with the Temperature, Cryst. Growth Des. 10 (2010) 5159-5168. doi: $10.1021 / \operatorname{cg} 100909 x$.

[39] L. Guennoun, J. El jastimi, F. Guédira, K. Marakchi, O.K. Kabbaj, A. El Hajji, S. Zaydoun, Molecular geometry and vibrational studies of 3,5-diamino-1,2,4-triazole using quantum chemical calculations and FT-IR and FT-Raman spectroscopies, Spectrochim. Acta. A. Mol. Biomol. Spectrosc. 78 (2011) 347-353. doi:10.1016/j.saa.2010.10.019.

[40] M.Y. Antipin, K.A. Lyssenko, K.Y. Suponitsky, H.A. Karapetyan, A.M. Petrosyan, Infrared and Raman spectra, structure and electron density distribution of l-arginine dioxalate, J. Mol. Struct. 792-793 (2006) 194-200. doi:10.1016/j.molstruc.2005.12.014.

[41] G. Socrates, Infrared and Raman characteristic group frequencies: tables and charts: Wiley, Chichester., Colloid Polym. Sci. (2004).

[42] V. Tsaryuk, V. Zolin, L. Puntus, V. Savchenko, J. Legendziewicz, J. Sokolnicki, R. Szostak, Vibronic spectra and details of the structure of europium nitrates with derivatives of 1,10- 
phenanthroline, J. Alloys Compd. 300-301 (2000) 184-192. doi:10.1016/S0925-8388(99)007203.

[43] J. Kincaid, K. Nakamoto, Observation of the Iron-Fluorine Vibration in the Resonance Raman Spectrum of Iron (III) Octaethylporphine Fluoride, Spectrosc. Lett. (1976) 19-21.

[44] Y. Suffren, F.-G. Rollet, O. Levasseur-Grenon, C. Reber, Ligand-centered vibrational modes as a probe of molecular and electronic structure: Raman spectroscopy of cis-Fe(1,10phenanthroline)2(NCS)2 and trans-Fe(pyridine)4(NCS)2 at variable temperature and pressure, Polyhedron. 52 (2013) 1081-1089. doi:10.1016/j.poly.2012.06.070.

[45] N. Bouzidia, N. Salah, B. Hamdi, A.B. Salah, Hydrothermal synthesis, structural elucidation, spectroscopic studies, thermal behavior and luminescence properties of a new 3-d compound: FeAlF2(C10H8N2)(HPO4)2(H2O), J. Mol. Struct. Complete (2017) 797-805. doi:10.1016/j.molstruc.2017.01.041.

[46] S. Blundell, Magnetism in Condensed Matter, 1 edition, Oxford University Press, Oxford; New York, 2001.

[47] Z. Amghouz, J. García, S. García-Granda, A. Clearfield, J. Rodriguez Fernandez, I. Pedro, J. Blanco, Lanthanide phosphonates: Synthesis, thermal stability and magnetic characterization, J. Alloys Compd. 536 (2012) S499-S503. doi:10.1016/j.jallcom.2011.12.029.

[48] G.M. Sheldrick, others, SHELXS86. Program for the solution of crystal structures, University of Göttingen: Göttingen, Germany, 1986. http://scholar.google.com/scholar?cluster=16996930491223202131\&hl=en\&oi=scholarr (accessed August 26, 2016).

[49] G.M. Sheldrick, SHELX-97: Programs for crystal structure analysis, Gött. Ger. (1997). http://scholar.google.com/scholar?cluster=18136807830013051904\&hl=en\&oi=scholarr (accessed August 26, 2016).

[50] L.J. Farrugia, WinGX suite for small-molecule single-crystal crystallography, J. Appl. Crystallogr. 32 (1999) 837-838. doi:10.1107/S0021889899006020.

[51] K. Brandenburg, M. Berndt, DIAMOND. Crystal Impact GbR, Bonn, Germany., J Appl Cryst. (1999) 1028-1029.

[52] P. Kubelka, New Contributions to the Optics of Intensely Light-Scattering Materials Part I, J. Opt. Soc. Am. 38 (1948) 448. doi:10.1364/JOSA.38.000448.

[53] W.E. Vargas, Inversion methods from Kubelka-Munk analysis, J. Opt. Pure Appl. Opt. 4 (2002) 452. doi:10.1088/1464-4258/4/4/314.

[54] A.K. Cheetham, C.N.R. Rao, R.K. Feller, Structural diversity and chemical trends in hybrid inorganic-organic framework materials, Chem. Commun. (2006) 4780-4795. doi:10.1039/B610264F. 
Table 1: Crystal data and structure refinement for $\left[\mathrm{Fe}_{3} \mathrm{~F}_{8}\left(\mathrm{H}_{2} \mathrm{O}\right)_{2}\right]\left(\mathrm{Am}_{2} \mathrm{TAZ}\right)_{2}$.

\begin{tabular}{|c|c|}
\hline Chemical formula & $\mathrm{Fe}_{3} \mathrm{~F}_{8}\left(\mathrm{H}_{2} \mathrm{O}\right)_{2} \mathrm{C}_{4} \mathrm{H}_{10} \mathrm{~N}_{10}$ \\
\hline Formula weight (g\mol) & 553.80 \\
\hline Temperature (K) & 298 \\
\hline Crystal system & Triclinic \\
\hline Space group & $\overline{\mathrm{P} \overline{1}}$ \\
\hline$a(\AA)$ & $7.100(2)$ \\
\hline$b(\AA)$ & $7.658(2)$ \\
\hline$c(\AA)$ & $8.321(2)$ \\
\hline$\alpha\left({ }^{\circ}\right)$ & $107.330(20)$ \\
\hline$\beta\left(^{\circ}\right)$ & $111.842(18)$ \\
\hline$\gamma\left({ }^{\circ}\right)$ & $93.049(17)$ \\
\hline $\mathrm{V}\left(\AA^{3}\right)$ & $394.01(17)$ \\
\hline $\bar{Z}$ & 1 \\
\hline$\rho_{\text {calculated }}\left({\mathrm{g} . \mathrm{cm}^{-3}}^{-3}\right)$ & 2.334 \\
\hline$\mu\left(\mathrm{mm}^{-1}\right)$ & 23.02 \\
\hline $\mathrm{F}(000)$ & 274 \\
\hline$\theta$ range $\left(^{\circ}\right)$ & $6.1-67.9$ \\
\hline Indexes range & $\begin{array}{l}\mathrm{h}=-8 \rightarrow 8 \\
\mathrm{k}=-9 \rightarrow 9 \\
\mathrm{l}=-8 \rightarrow 10\end{array}$ \\
\hline Measured reflections & 2541 \\
\hline Unique reflections & 1477 \\
\hline Observed reflections $(\mathrm{I}>2 \sigma(\mathrm{I}))$ & 1216 \\
\hline $\mathrm{R}_{\text {int }}$ & 0.034 \\
\hline $\mathrm{R}$ & 0.058 \\
\hline $\mathrm{WR}_{2}$ & 0.176 \\
\hline Goof $=S$ & 1.10 \\
\hline$\Delta \rho_{\max } \backslash \Delta \rho_{\min }\left(\mathrm{e} \AA^{-3}\right)$ & $1.08 \backslash-0.93$ \\
\hline
\end{tabular}


Table 2: Main interatomic distances $(\AA)$ and bond angles $\left(^{\circ}\right)$ of $\left[\mathrm{Fe}_{3} \mathrm{~F}_{8}\left(\mathrm{H}_{2} \mathrm{O}\right)_{2}\right]\left(\mathrm{Am}_{2} \mathrm{TAZ}\right)_{2}$.

\begin{tabular}{|c|c|}
\hline \multicolumn{2}{|c|}{ Distances $(\mathbf{A})$} \\
\hline $\mathrm{Fe}(1)-\mathrm{F}(1)$ & $2.131(4)$ \\
\hline $\mathrm{Fe}(1)-\mathrm{OW}(1)$ & $2.089(6)$ \\
\hline $\mathrm{Fe}(1)-\mathrm{N}(1)$ & $2.109(5)$ \\
\hline $\mathrm{Fe}(2)-\mathrm{F}(1)$ & $1.906(4)$ \\
\hline $\mathrm{Fe}(2)-\mathrm{F}(2)$ & $1.962(4)$ \\
\hline $\mathrm{Fe}(2)-\mathrm{N}(2)$ & $2.097(5)$ \\
\hline $\mathrm{Fe}(3)-\mathrm{F}(2)$ & $1.957(4)$ \\
\hline $\mathrm{Fe}(3)-\mathrm{F}(3)$ & $1.890(4)$ \\
\hline $\mathrm{Fe}(3)-\mathrm{F}(4)$ & $1.937(4)$ \\
\hline $\mathrm{N}(1)-\mathrm{N}(2)$ & $1.412(7)$ \\
\hline $\mathrm{N}(1)-\mathrm{C}(2)$ & $1.306(9)$ \\
\hline $\mathrm{N}(2)-\mathrm{C}(1)$ & $1.299(8)$ \\
\hline $\mathrm{N}(3)-\mathrm{C}(1)$ & $1.356(8)$ \\
\hline $\mathrm{N}(3)-\mathrm{C}(2)$ & $1.357(9)$ \\
\hline $\mathrm{N}(4)-\mathrm{C}(1)$ & $1.349(9)$ \\
\hline $\mathrm{N}(5)-\mathrm{C}(2)$ & $1.350(9)$ \\
\hline \multicolumn{2}{|c|}{ Angles $\left(^{\circ}\right)$} \\
\hline $\mathrm{F}(1)-\mathrm{Fe}(1)-\mathrm{OW}(1)$ & $90.1(2)$ \\
\hline $\mathrm{F}(1)-\mathrm{Fe}(1)-\mathrm{N}(1)$ & $84.01(17)$ \\
\hline $\mathrm{OW}(1)-\mathrm{Fe}(1)-\mathrm{N}(1)$ & $87.8(2)$ \\
\hline $\mathrm{F}(1)-\mathrm{Fe}(2)-\mathrm{F}(2)$ & $89.37(18)$ \\
\hline $\mathrm{F}(1)-\mathrm{Fe}(2)-\mathrm{N}(2)$ & $88.56(18)$ \\
\hline $\mathrm{F}(2)-\mathrm{Fe}(2)-\mathrm{N}(2)$ & $88.0(2)$ \\
\hline $\mathrm{F}(2)-\mathrm{Fe}(3)-\mathrm{F}(3)$ & $90.5(2)$ \\
\hline $\mathrm{F}(2)-\mathrm{Fe}(3)-\mathrm{F}(4)$ & $89.22(18)$ \\
\hline $\mathrm{F}(3)-\mathrm{Fe}(3)-\mathrm{F}(4)$ & $88.16(19)$ \\
\hline $\mathrm{Fe}(1)-\mathrm{F}(1)-\mathrm{Fe}(2)$ & $123.06(19)$ \\
\hline$\overline{F e}(2)-\mathrm{F}(2)-\mathrm{Fe}(3)$ & $155.4(3)$ \\
\hline
\end{tabular}




\begin{tabular}{|c|c|}
\hline $\mathrm{Fe}(1)-\mathrm{N}(1)-\mathrm{N}(2)$ & $118.9(4)$ \\
\hline $\mathrm{Fe}(1)-\mathrm{N}(1)-\mathrm{C}(2)$ & $129.0(4)$ \\
\hline $\mathrm{N}(2)-\mathrm{N}(1)-\mathrm{C}(2)$ & $106.4(5)$ \\
\hline $\mathrm{Fe}(2)-\mathrm{N}(2)-\mathrm{N}(1)$ & $115.7(4)$ \\
\hline $\mathrm{Fe}(2)-\mathrm{N}(2)-\mathrm{C}(1)$ & $135.6(4)$ \\
\hline $\mathrm{N}(1)-\mathrm{N}(2)-\mathrm{N}(1)$ & $107.4(5)$ \\
\hline $\mathrm{C}(1)-\mathrm{N}(3)-\mathrm{C}(2)$ & $106.1(5)$ \\
\hline $\mathrm{N}(2)-\mathrm{C}(1)-\mathrm{N}(3)$ & $109.9(6)$ \\
\hline $\mathrm{N}(2)-\mathrm{C}(1)-\mathrm{N}(4)$ & $127.4(6)$ \\
\hline $\mathrm{N}(3)-\mathrm{C}(1)-\mathrm{N}(4)$ & $122.7(6)$ \\
\hline $\mathrm{N}(1)-\mathrm{C}(2)-\mathrm{N}(3)$ & $110.2(6)$ \\
\hline $\mathrm{N}(1)-\mathrm{C}(2)-\mathrm{N}(5)$ & $126.1(6)$ \\
\hline $\mathrm{N}(3)-\mathrm{C}(2)-\mathrm{N}(5)$ & $123.6(6)$ \\
\hline
\end{tabular}


Table 3: Infrared and Raman frequencies for $\left[\mathrm{Fe}_{3} \mathrm{~F}_{8}\left(\mathrm{H}_{2} \mathrm{O}\right)_{2}\right]\left(\mathrm{Am}_{2} \mathrm{TAZ}\right)_{2}$.

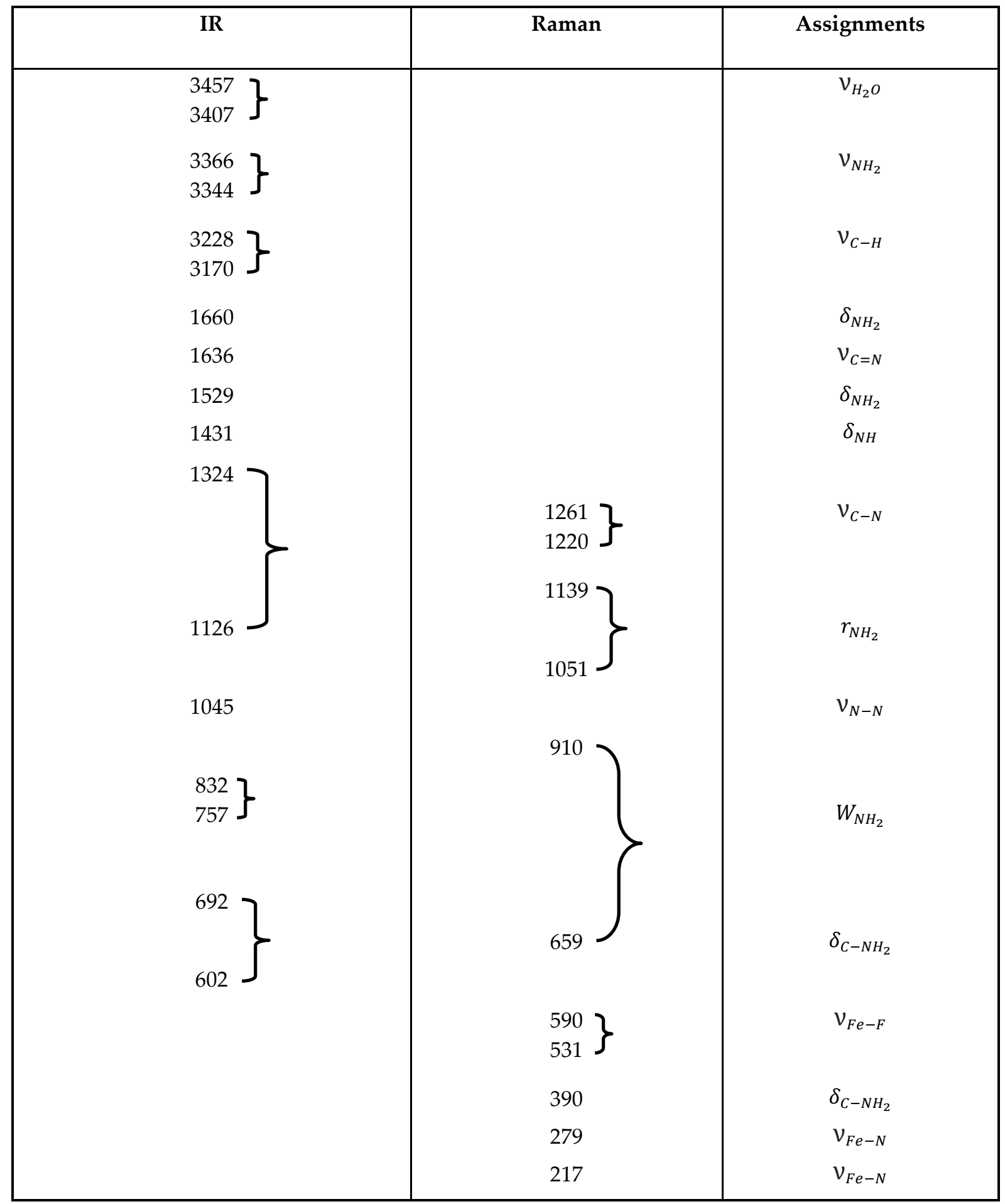


Table 4: Mass susceptibility, paramagnetic temperature, molar constant of Curie, effective moment magnetic and reliability factor for adjusting the Curie law for the new hybrid $\left[\mathrm{Fe}_{3} \mathrm{~F}_{8}\left(\mathrm{H}_{2} \mathrm{O}\right)_{2}\right]\left(\mathrm{Am}_{2} \mathrm{TAZ}\right)_{2}$.

\begin{tabular}{|c|c|c|c|c|}
\hline $\begin{array}{c}\text { Sample } \\
\text { Composition }\end{array}$ & $\chi_{m}\left(\mathbf{c m}^{\mathbf{3}} / \mathbf{g}\right)$ & $\theta \mathbf{p}(\mathbf{K})$ & $\begin{array}{c}\mathrm{Cm} \\
\left(\mathbf{c m}^{\mathbf{3}} \cdot \mathbf{K} / \mathbf{m o l}\right)\end{array}$ & $\mu_{\text {eff }}\left(\boldsymbol{\mu}_{\boldsymbol{B}}\right)$ \\
\hline $\mathrm{Fe}_{3} \mathrm{~F}_{8}\left(\mathrm{H}_{2} \mathrm{O}\right)_{2} \mathrm{C}_{4} \mathrm{H}_{10} \mathrm{~N}_{10}$ & $4.657(3) \cdot 10^{-5}$ & $-200(1)$ & $6.0(2)$ & $6.9(2)$ \\
\hline
\end{tabular}




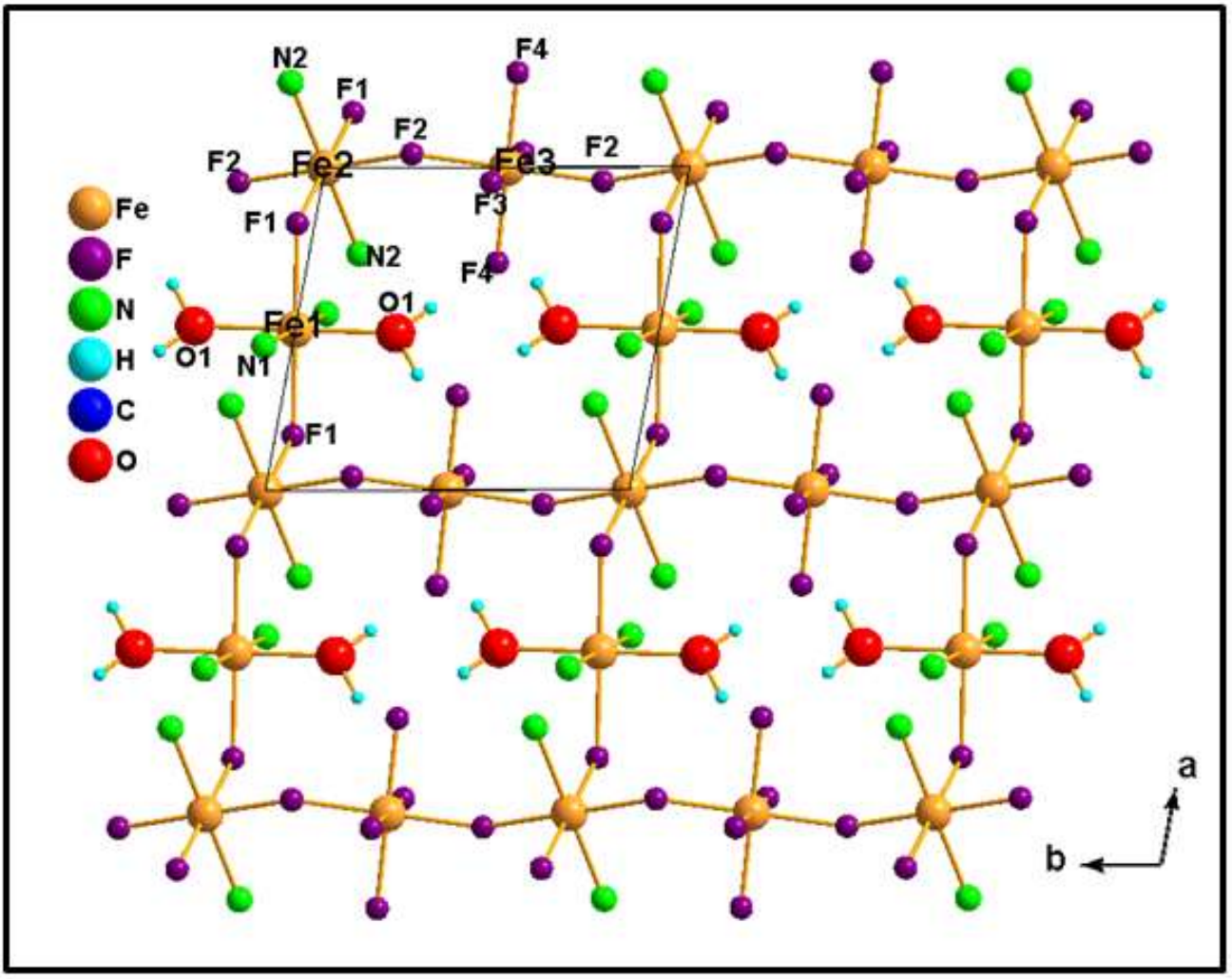

Figure 1. The projection of the layer building of the $\left[\mathrm{Fe}_{3} \mathrm{~F}_{8}\left(\mathrm{H}_{2} \mathrm{O}\right)_{2}\right]\left(\mathrm{Am}_{2} \mathrm{TAZ}\right)_{2}$ compound in the (001) plane. 


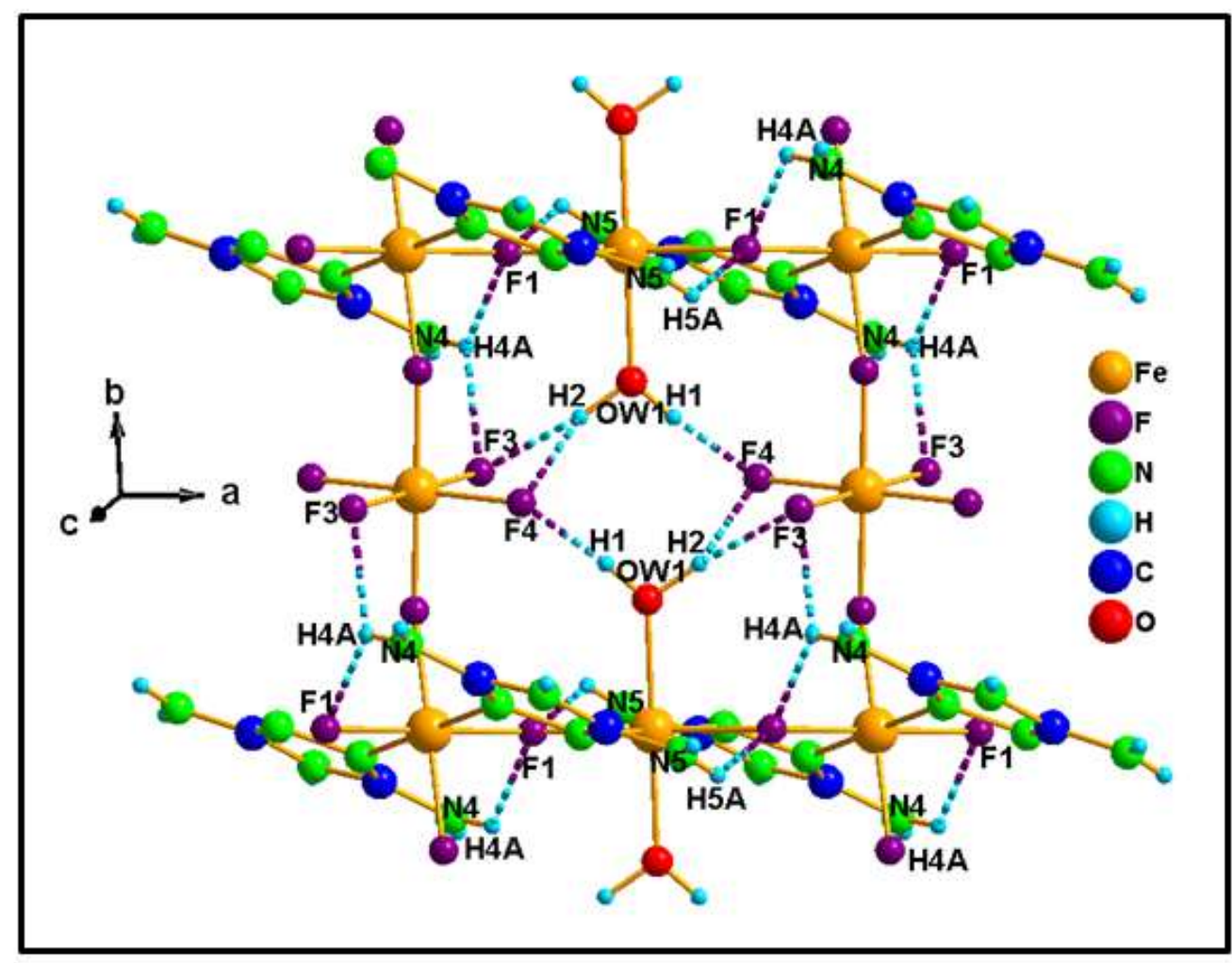

Figure 2. View of Hydrogen bond in the $\left[\mathrm{Fe}_{3} \mathrm{~F}_{8}\left(\mathrm{H}_{2} \mathrm{O}\right)_{2}\right]\left(\mathrm{Am}_{2} \mathrm{TAZ}\right)_{2}$ structure. 


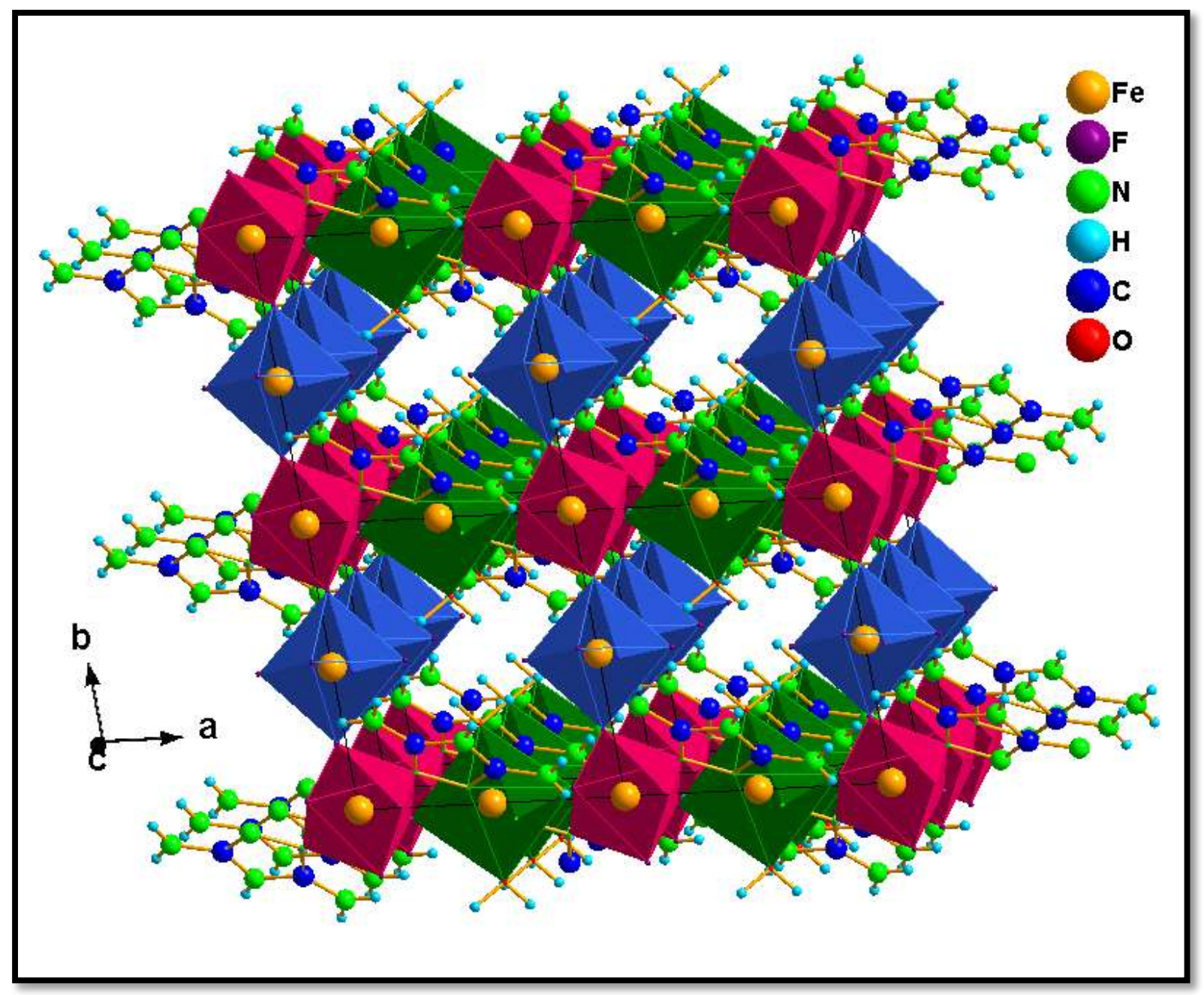

Figure 3. Perspective view of the whole structure $\left[\mathrm{Fe}_{3} \mathrm{~F}_{8}\left(\mathrm{H}_{2} \mathrm{O}\right)_{2}\right]\left(\mathrm{Am}_{2} \mathrm{TAZ}\right)_{2}$ in the [001] direction. 


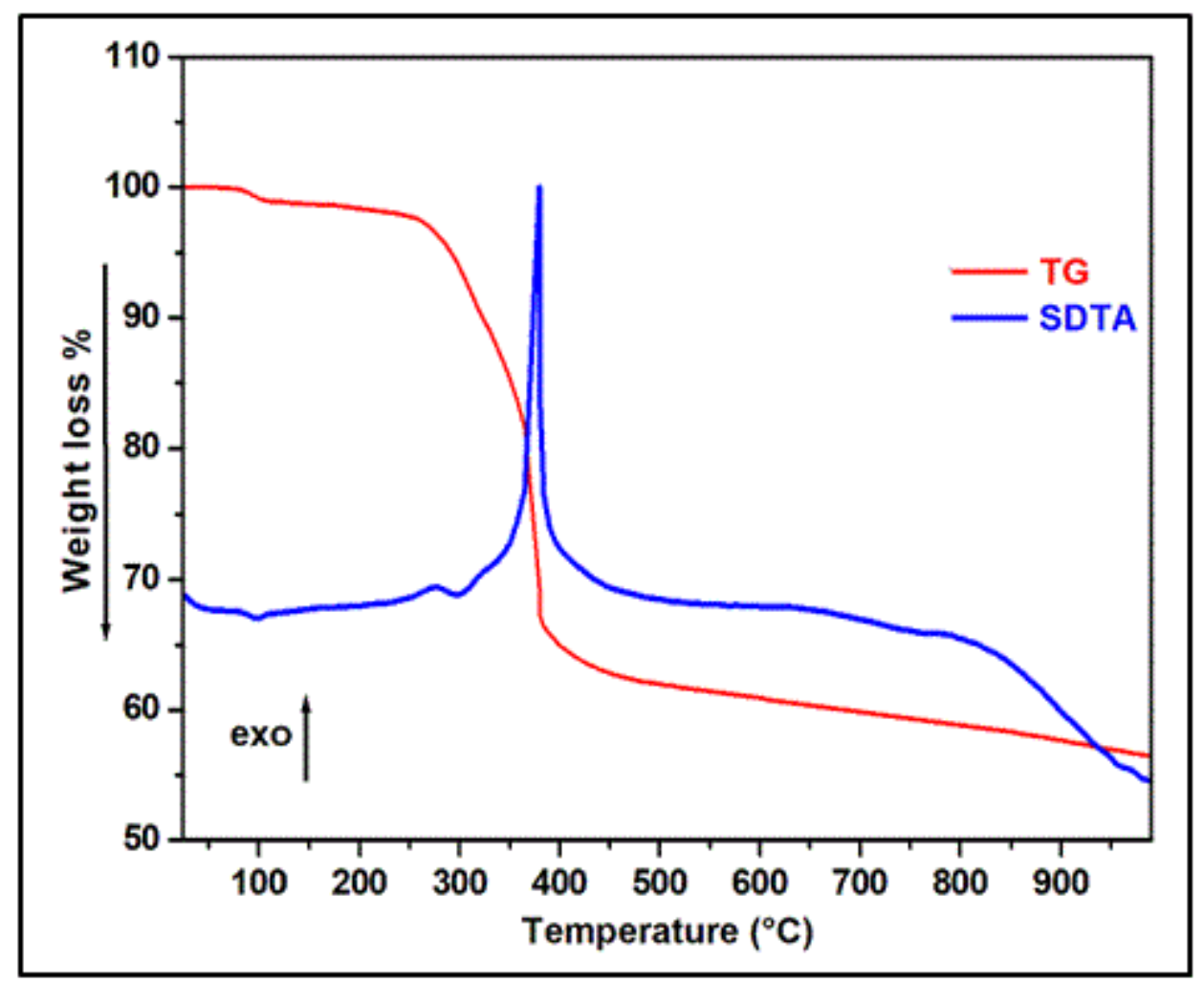

Figure 4. TG / SDTA curves of heating of $\left[\mathrm{Fe}_{3} \mathrm{~F}_{8}\left(\mathrm{H}_{2} \mathrm{O}\right)_{2}\right]\left(\mathrm{Am}_{2} \mathrm{TAZ}\right)_{2}$ material. 


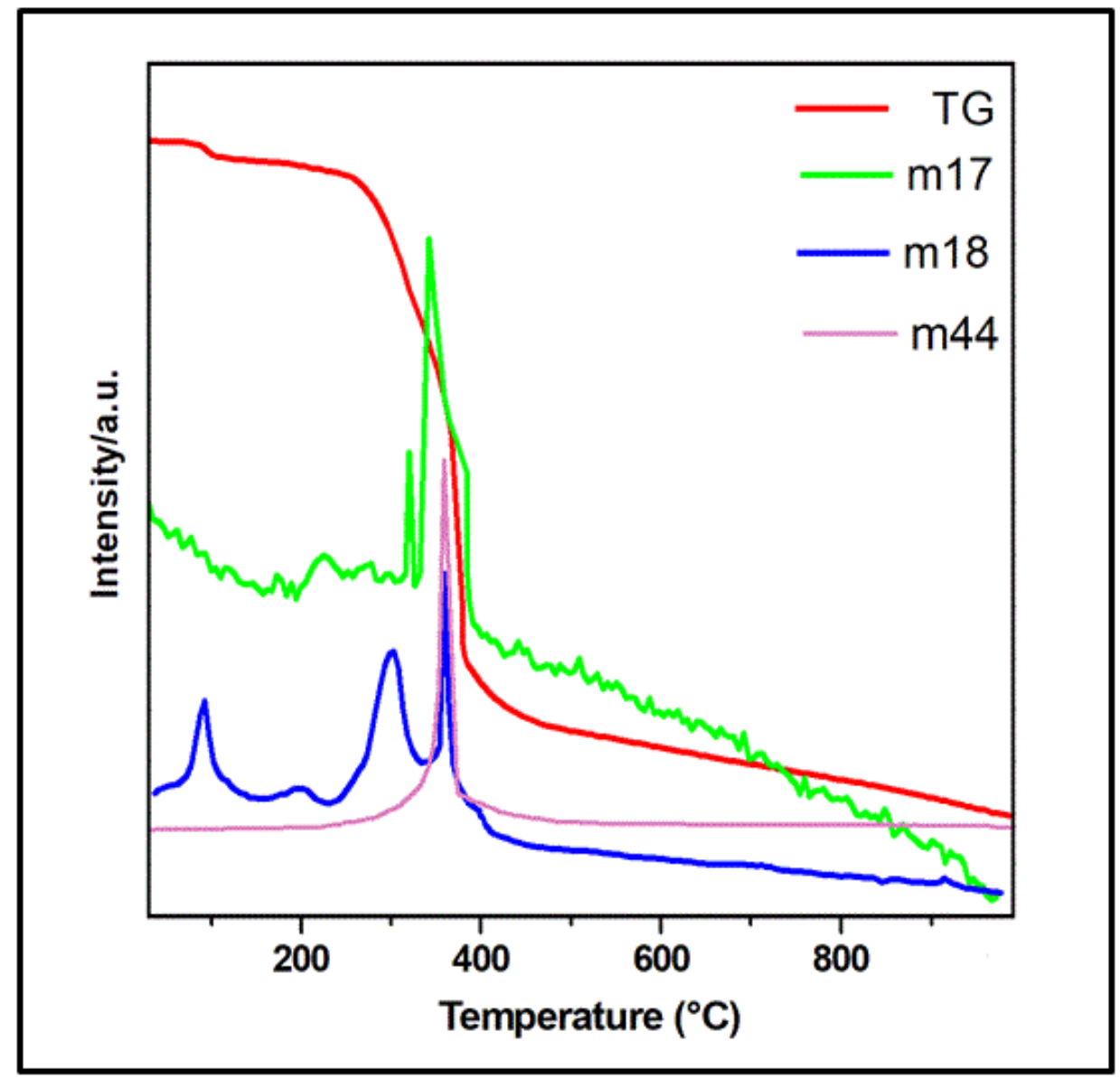

Figure 5. $\mathrm{m} / \mathrm{z} 17\left(\mathrm{NH}_{3}\right), \mathrm{m} / \mathrm{z} 18\left(\mathrm{H}_{2} \mathrm{O}\right)$ and $\mathrm{m} / \mathrm{z} 44\left(\mathrm{CO}_{2}\right)$ MS signals of evacuated vapours. 


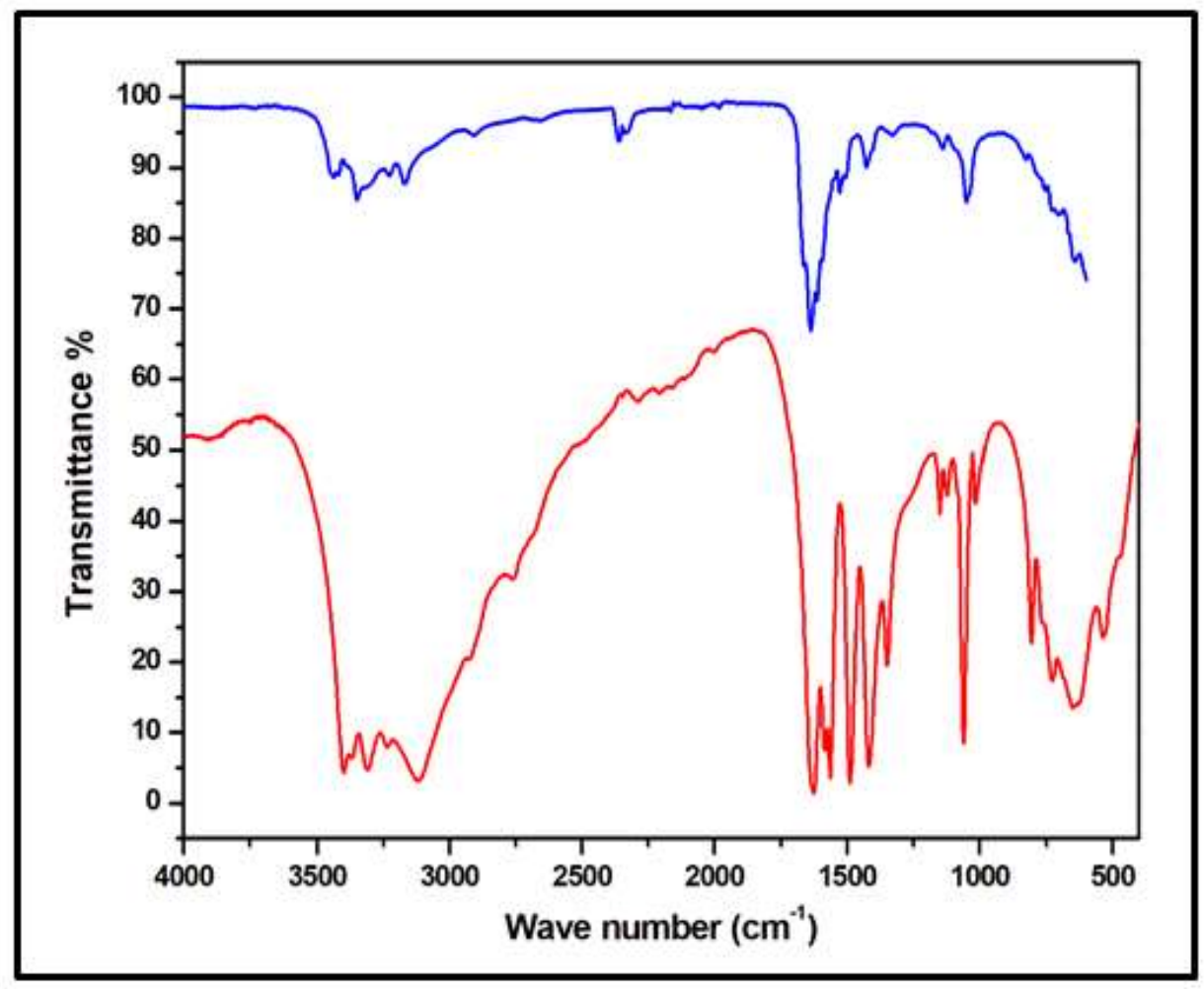

Figure 6. Infrared spectra of the pure ligand (red) and $\left[\mathrm{Fe}_{3} \mathrm{~F}_{8}\left(\mathrm{H}_{2} \mathrm{O}\right)_{2}\right]\left(\mathrm{Am}_{2} \mathrm{TAZ}\right)_{2}$ compound (blue). 


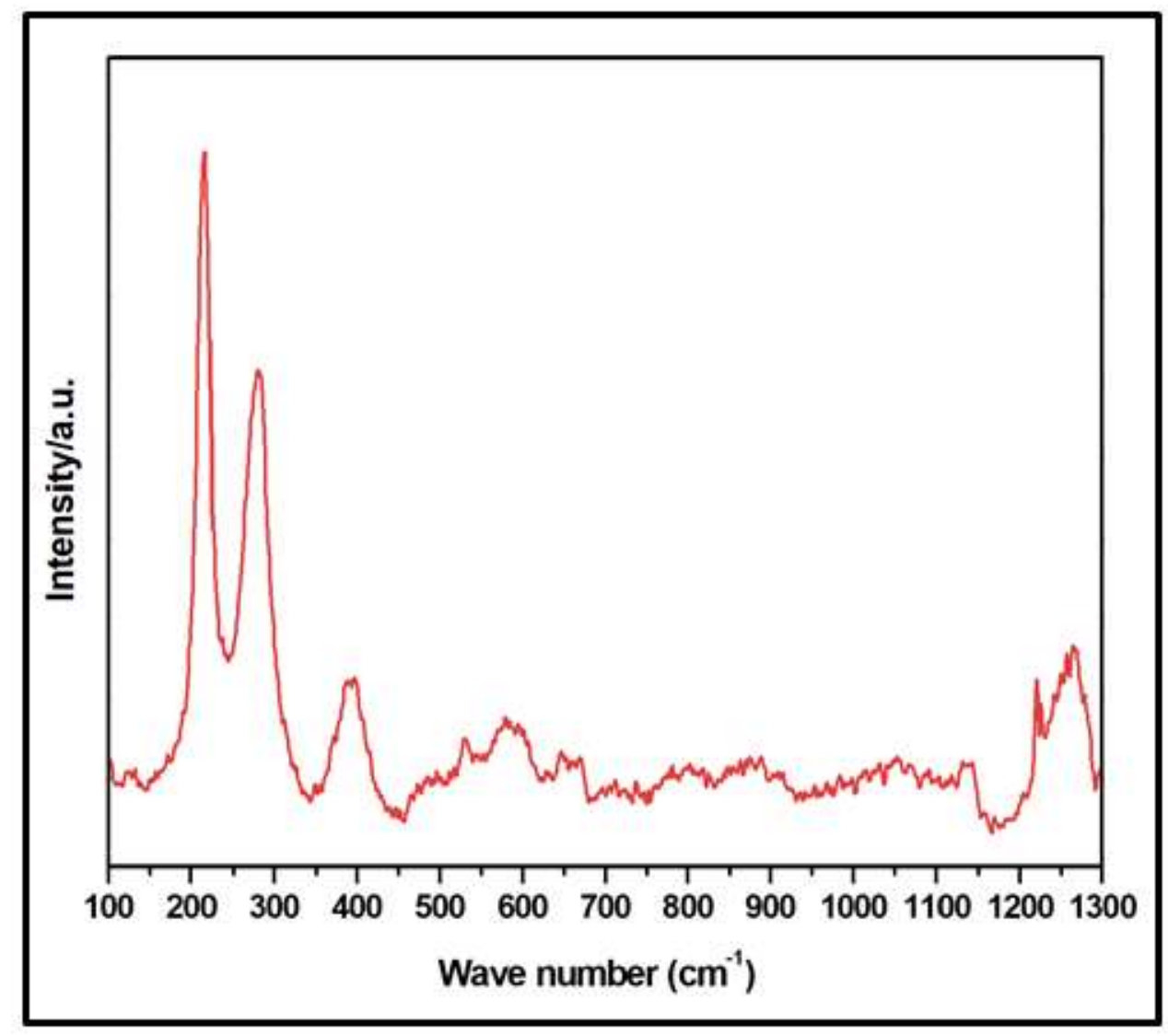

Figure 7. Raman spectrum of $\left[\mathrm{Fe}_{3} \mathrm{~F}_{8}\left(\mathrm{H}_{2} \mathrm{O}\right)_{2}\right]\left(\mathrm{Am}_{2} \mathrm{TAZ}\right)_{2}$ compound. 


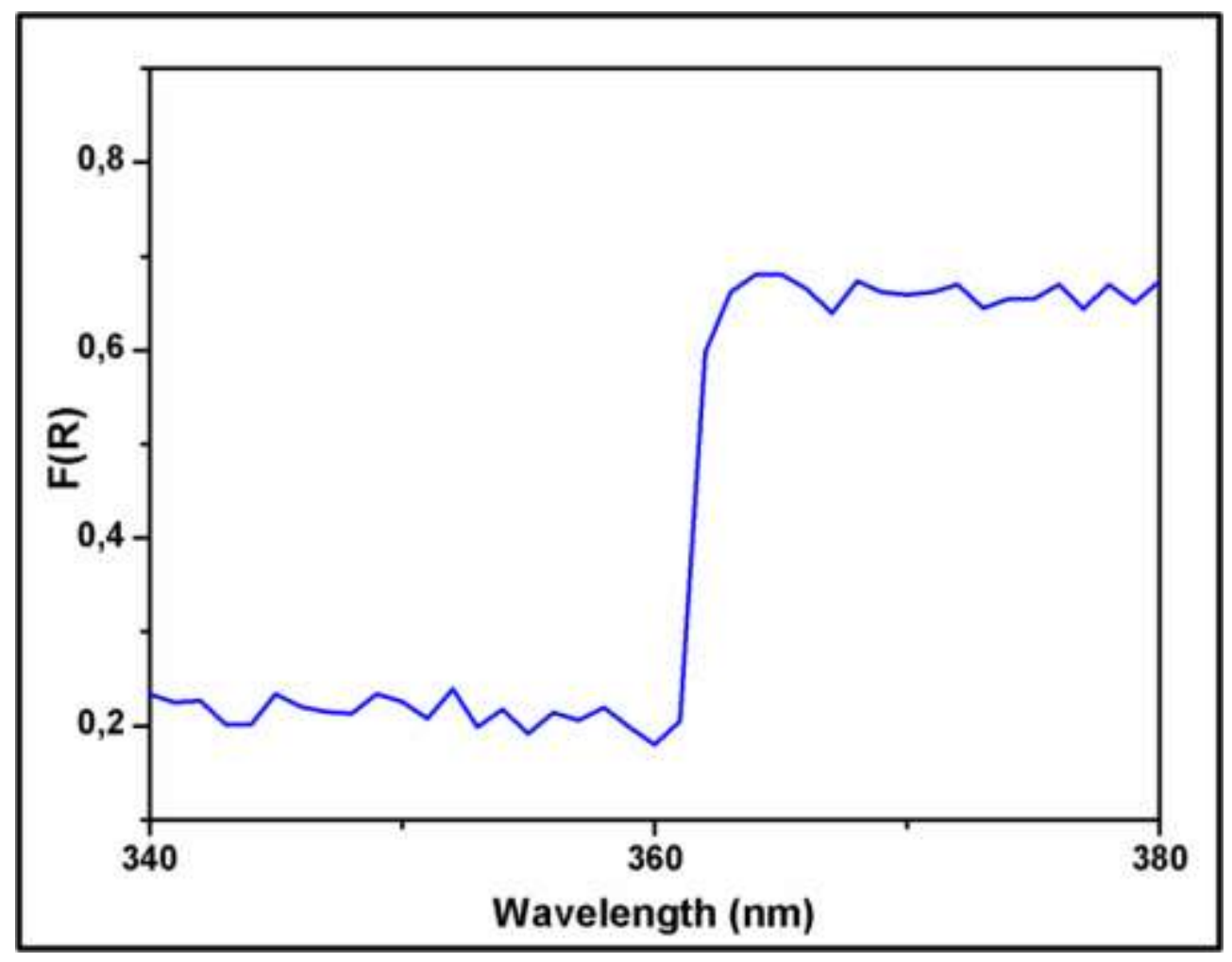

Figure 8. UV-Vis diffuse-reflectance spectrum of $\left[\mathrm{Fe}_{3} \mathrm{~F}_{8}\left(\mathrm{H}_{2} \mathrm{O}\right)_{2}\right]\left(\mathrm{Am}_{2} \mathrm{TAZ}\right)_{2}$ after application of the Kubelka-Munk transformation. 


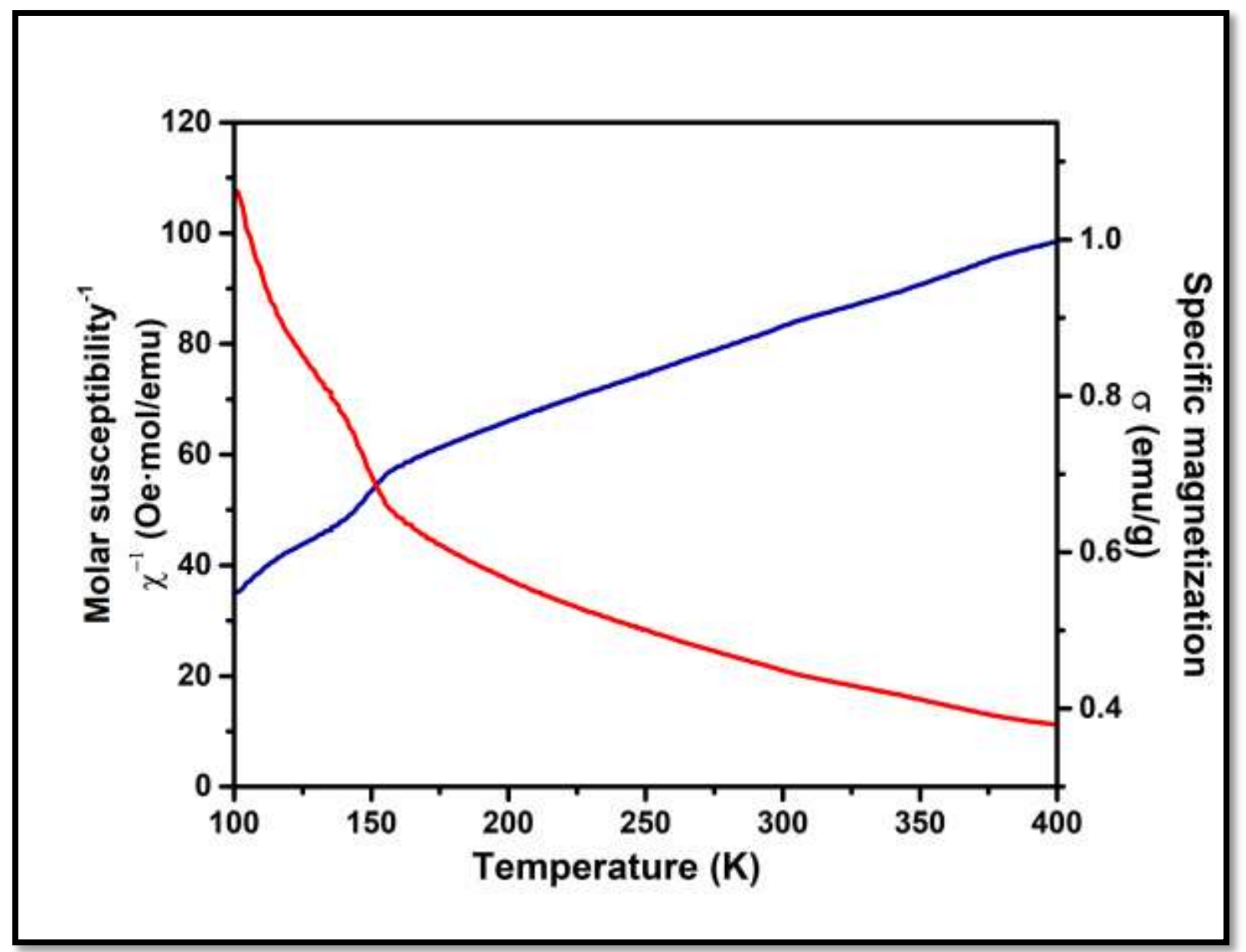

Figure 9. Magnetic susceptibility $\mathrm{M}(\mathrm{T})$ (red) and the inverse of magnetic susceptibility (blue) for the $\left[\mathrm{Fe}_{3} \mathrm{~F}_{8}\left(\mathrm{H}_{2} \mathrm{O}\right)_{2}\right]\left(\mathrm{Am}_{2} \mathrm{TAZ}\right)_{2}$ compound measured under an applied magnetic field of $10 \mathrm{kOe}$. 


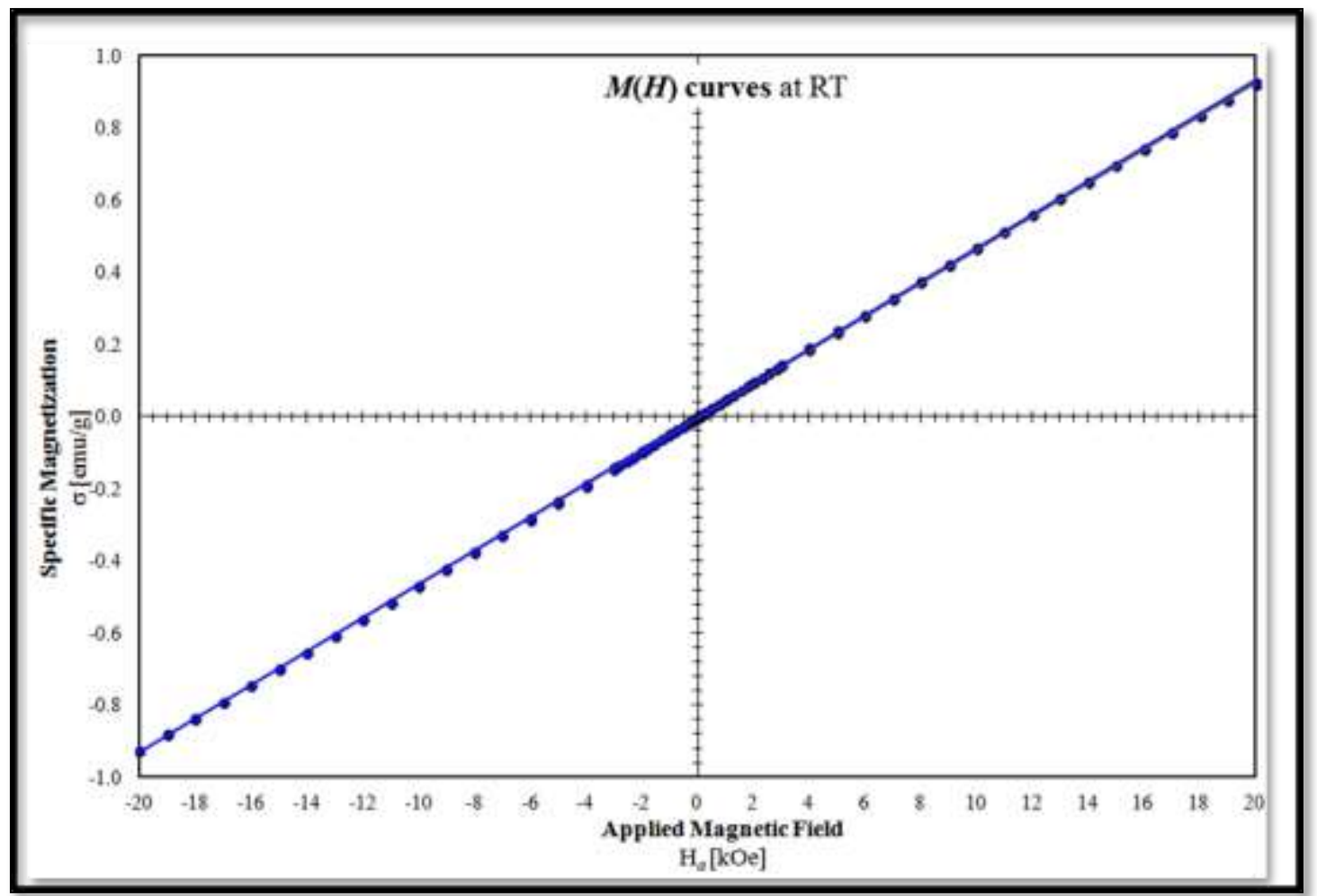

Figure 10. Magnetic signal for the $\left[\mathrm{Fe}_{3} \mathrm{~F}_{8}\left(\mathrm{H}_{2} \mathrm{O}\right)_{2}\right]\left(\mathrm{Am}_{2} \mathrm{TAZ}\right)_{2}$ material measured during a close loop with maximum applied magnetic field of $20 \mathrm{kOe}$ at room temperature. 